\title{
APPORTIONMENT OF INCOME FROM A SPOUSE'S SEPARATELY OWNED PROPERTY
}

California, in accordance with the majority of community property states, provides that the rents and profits from a spouse's separate property are also separate property. ${ }^{1}$ The earnings of either spouse, however, form the essence of the community property system, ${ }^{2}$ and are clearly allocable to the community. ${ }^{3}$ If either spouse devotes time, labor, and skill durimg marriage to the production of income from separate property, these two concepts come into direct conflict. ${ }^{4}$ In such cases problems arise whether the income should be divided between the community and separate interests, ${ }^{5}$ and if so, what method of apportionment should be used. ${ }^{6}$ In Cahifornia, the proceeds of such separately owned property are theoretically coin-

1 CAL. CIv. Code $\$ 162$ : "All property of the wife, owned by her before marriage, and that acquired afterwards by gift, bequest, devise, or descent, with the rents, issues, and profits thereof, is her separate proprety." CAL. CIV. CODE $\$ 163$ : "All property owned by the husband before marriage, and that acquired afterwards by gift, bequest, devise, or descent, with the rents, issues, and profits thereof, is his separate property."

In Arizona, Nevada, New Mexico, and Washington the rents and profits of separate property remain separate. Aruz. Rev. Stat. ANN. § 25-213 (1956) ; NEv. Rev. Star. § 123.130 (1957); N.M. Stat. ANn. \$\$ 57-3-4, -5 (1953); WASH. Rev. CoDE $\$ \S 26.16 .010, .020$ (1961). In Idaho, Louisiana, and Texas they are community property. IDAHo CoDE ANN. §32-903 (1948); LA. Rev. STaT. arts. 2334-35, 2386, 2402 (1952) ; TEx. REv. CIv. STAT. ANN, arts. 4613-14 (1960). See generally 2 Aarerican Law of Property $\$ 7.12$ (Casner ed. 1952) ; BuRby, Cases on CoMarontty Property 142 (1933) ; 4 Poweit, Reas Property 684 n.41 (1954); 2 Tiffany, Real Property \& 439 (3d ed. 1939); 3 Vernier, AMTerican Fammi Laws 210-12 (1935).

2 Balingger, Comanunity Property $\$ 11$ (1895) [hereinafter cited as Ballingerd] B Burby, Real Property \& 204 (2d ed. 1954); de Funtak, Principles of Comarunity Property $\$ 66$ (1943) [hereinafter cited as DE FunIar]; McKay, Comaruntry Property $\$ 296$ (2d ed. 1925); Evans, Primary Sources of Acquisition of Community Property, 10 CaLIF. L. REv. 271 (1922); Pomeroy, Community Property, 4 West CoAST RPTR. 305 (1884); see Yesler v. Hochstettler, 4 Wash. 349, 30 Pac. 398 (1892).

3 Washburn v. Washhurn, 9 Cal. 475, 476 (1858); 4 Witren, Suararary of California LAw 2720 (7th ed. 1960); see Martin v. Southern Pac. Co., 130 Cal. 285, 62 Pac. 515 (1900); Bekins v. Dieterle, 5 Cal. App. 690, 91 Pac. 173 (1907).

${ }^{4}$ See Hute, Texas Cases on Martal Property 214 (1955); McKay, op. cit. supra note 2, at § 289; Wood, The Conarunity Property LaW OF NEW Mexico §§ 39-40 (1954); Evans, supra note 2, at 279.

6 Neither Arizona nor Nevada seem to make any apportionment. See Rundle v. Winters, 38 Ariz. 239, 298 Pac. 929 (1931); Ormachea v. Ormachea, 67 Nev. 273, 217 P.2d 355 (1950). See also Guthrie v. Guthrie, 73 Ariz. 423, 242 P.2d 549 (1952); Lawson v. Ridgeway, 72 Ariz. 253, 233 P.2d 459 (1951); Porter v. Porter, 67 Ariz. 273, 195 P.2d 132 (1948); Anderson v. Anderson, 65 Ariz. 184, 177 P.2d 227 (1947); Estate of Torrey, 54 Ariz. 369, 95 P.2d 990 (1939); Youngworth v. Jewell, 15 Nev. 45 (1880); Grimes v. Grimes, 52 F.2d 171 (D. Nev. 1931). Washington makes an apportionment in certain cases. See Hamlin v. Merlino, 44 Wash. 2d 851, 272 P.2d 125 (1954); Estate of Dewey, 13 Wash.2d 220, 124 P.2d 805 (1942). See also Jacobs v. Hoitt, 119 Wash. 283, 205 Pac. 414 (1922); Yesler v. Hochstettler, 4 Wash. 349, 30 Pac. 398 (1892). New Mexico seems to treat the problem in the same manner as California. See Laughlin v. Laughlin, 49 N.M. 20, 155 P.2d 1010 (1944); Katson v. Katson, 43 N.M. 214, 89 P.2d 524 (1939). See generally Annot., 29 A.L.R.2d 530 (1953).

6 See King, The Challenge of Apportionment, 37 WASH. L. REv. 483 (1962). In New Mexico and Washington the community seems to be limited to the salary that the husband draws from the business. See Katson v. Katson, 43 N.M. 214, 89 P.2d 524 (1939) ; Hamlin v. Merlino, 44 Wash. 2d 851, 272 P.2d 125 (1954); Estate of Dewey, 13 Wash. 2d 220, 124 P.2d 805 (1942). In New Mexico the income from a farm is apportioned in accord with the rule established in Pereira v. Pereira, 156 Cal. 1, 103 Pac. 488 (1909). Laughlin v. Laughlin, 49 N.M. 20, 155 P.2d 1010 (1944); see text accompanying notes 9-10 infra. 
munity property to the extent they reflect the effort of the spouses, and separate to the extent they reflect the earning power of the separate property itself. ${ }^{7}$ In practice, however, it is not clear how this theoretical apportionment is to be made. ${ }^{8}$ An analysis of this problem, including a proposed solution, is the main objective of this comment.

The early cases of Pereira v. Pereira ${ }^{9}$ and Estate of Pepper ${ }^{10}$ are at the root of the existing confusion in California. The Pereira case held that when a husband continues to work after marriage in his separately owned business, the revenue from the busmess must be apportioned between the community and lis separate estate. In making this apportionment, the California Supreme Court decided that the husband's separately owned capital, mvested in what was a profitable business, should be credited with at least the legal interest rate ${ }^{11}$ with the remainder of the business profits going to the community. But, one year later in Estate of Pepper, ${ }^{12}$ the same court refused to apportion the proceeds of the husband's separately owned nursery business because such proceeds were products of the land. The entire business profit was held to be the husband's separate property, notwithstanding the fact that during the marriage the husband devoted his time and labor exclusively to running the nursery. ${ }^{13}$

In Estate of Neilson, ${ }^{14}$ decided in May of 1962, the California Supreme Court overruled the Pepper case, holding that profit resulting from the sale of products of land could be apportioned in the same manner as profits from other commercial ventures. ${ }^{15}$ In Neilson Justice Traynor set forth a method of apportionment based on several relevant California cases. ${ }^{16}$ These cases, however, do not appear to be reconcilable, since they rely to some extent on the basically conflicting doctrines of Pepper and Pereira. ${ }^{17}$ Consequently, the extent to which Neilson expunges the mfluence of Pepper and resolves the problems of apportionment is not

7 Estate of Neilson, 57 Cal.2d 733, 740, 371 P.2d 745, 749, 22 Cal. Rptr. 1, 4-5 (1962); Huber v. Huber, 27 Cal. 2d 784, 792, 167 P.2d 708, 713 (1946); Estate of Gold, 170 Cal. 621, 623, 151 Pac. 12, 13 (1915) ; Pereira v. Pereira, 156 Cal. 1, 7, 103 Pac. 488, 491 (1909); sce Annot., 55 A.L.R.2d 960, 965 (1957).

${ }^{8}$ See Strohm v. Strohm, 182 Cal. App. 2d 53, 62, 5 Cal: Rptr. 884, 889 (1960); Tassi v. Tassi, 160 Cal. App. 2d 680, 690, 325 P.2d 872, 878 (1958); 4 Witkin, Summary of CaLIFORNIA LAW 2725 (7th ed. 1960).

${ }^{9} 156$ Cal. 1, 103 Pac. 488 (1909).

10158 Cal. 619, 112 Pac. 62 (1910).

11156 Cal. at 7, 103 Pac. at 491.

12158 Cal. 619, 112 Pac. 62 (1910).

13 Id. at 624, 112 Pac. at 64. See Verrati, Cases on Caltfornia Communtty Property 117-18 (1960).

1457 Cal. 2d 733, 371 P.2d 745, 22 Cal. Rptr. 1 (1962).

15 Id. at 740, 371 P.2d at 749, 22 Cal. Rptr. at 4-5. The holding in Neilson overruling Pepper was reaffirmed by the California Supreme Court in Mayhood v. La Rosa, 58 A.C. 510, 374 P.2d 805, 24 Cal. Rptr. 837 (1962), and im Machado v. Machado, 58 A.C. 513,375 P.2d 55, 25 Cal. Rptr. 87 (1962).

16 Estate of Arstein, 56 Cal. 2d 239, 364 P.2d 33, 14 Cal. Rptr. 809 (1961); Gilmore v. Gilmore, 45 Cal. 2d 142, 287 P.2d 769 (1955); Harrold v. Harrold, 43 Cal. 2d 77, 271 P.2d 489 (1954); Huber v. Huber, 27 Cal. 2d 784, 167 P.2d 708 (1946); Pereira v. Percira, 156 Cal. 1, 103 Pac. 488 (1909); Estate of Cudworth, 133 Cal. 462, 65 Pac. 1041 (1901); Tassi v. Tassi, 160 Cal. App. 2d 680, 325 P.2d 872 (1958); Randolph v. Randolpb, 118 Cal. App. 2d 584, 258 P.2d 547 (1953); Logan v. Forster, 114 Cal. App. 2d 587, 250 P.2d 730 (1952); Jenkins v. Jenkins, 110 Cal. App. 2d 663, 243 P.2d 79 (1952); Stice v. Stice, 81 Cal. App. 2d 792, 185 P.2d 402 (1947) ; Cozzi v. Cozzi, 81 Cal. App. 2d 229, 183 P.2d 739 (1947); Witaschek v. Witaschek, 56 Cal. App. 2d 277, 132 P.2d 600 (1942); Estate of Barnes, 128 Cal. App. 489, 17 P.2d 1046 (1932); McDuff v. McDuff, 48 Cal. App. 175, 191 Pac. 957 (1920).

17 See text following note 164 infra. 
clear. The holdings of Pepper and Pereira, and the inconsistent manner in which subsequent cases have applied the two decisions, may still leave some uncertainty concerning the proper method for apportioning profits. ${ }^{18}$

While otherwise adopting the common law, ${ }^{19}$ the framers of the first California constitution chose to retain ${ }^{20}$ the civil law community property system. ${ }^{21}$ Common law principles, Lowever, infiltrated that system in Pereira ${ }^{22}$ and Pepper, ${ }_{2}^{23}$ thus initially contributing to the confusion. ${ }^{24}$ A complete analysis of Neilson, therefore, must begin witl the cases leading up to Pereira and Pepper. Sucls an historical treatment is undertaken in part I of this comment. ${ }^{25}$ Part II develops the law from Pereira and Pepper to Neilson, ${ }^{26}$ and part III discusses the present impact of Neilson. ${ }^{27}$ Finally, part IV proposes a method of apportionment for successful $^{28}$ and losing ${ }^{29}$ businesses.

\section{I}

EARLY DEVELOPMENT OF THE PROBLEM

\section{A. Rents and Profits of Separate Property Are Not Solely Community Property}

The community property system was in force when California was under Mexican rule, ${ }^{30}$ and it was from the Spanisl-Mexican civil law that the present community property system was derived. ${ }^{31}$ Under the Spamish-Mexican system the

18 See note 8 supra. See also 1 DEFUNIAK $\$ 72$, at 14 (Supp. 1948).

19 Conary, The Historic Spanish Origin of CaItfornia's Community Property Law 9 (1957) [hereinafter cited as CONaY] ; McMurray, The Beginnings of the Community Property System in California and the Adoption of the Common Law, 3 CALIF. L. Rev. 359, 373-76 (1915).

${ }^{20}$ See Huie, The Texas Constitutional Definition of the Wife's Separate Property, 35 TEXas

L. REv. 1054 (1957).

21 See note 31 and text accompanying note 46 infra.

22 See text following note 111 infra.

23 See text following note 183 infra.

24 The earlier decision in George v. Ransom, 15 Cal. 322 (1860), relied on common law notions to create the problem of apportionment in the first place, and without this decision the rents and profits of separate property would have been classified as wholly community property. See text following note 37 infra.

25 See text following note 29 infra.

26 See text following note 101 infra.

27 See text following note 244 infra.

28 See text following note 302 infra.

20 See text following note 330 infra.

301 Armstrong, CaLIFornia Fammir Law 431 (1953) [hereinafter cited as ArMstrong]; ConMT 4.

31 Stewart v. Stewart, 199 Cal. 318, 249 Pac. 197 (1926); Roberts v. Wehmeyer, $191 \mathrm{Cal}$. 601, 218 Pac. 22 (1923) ; Spreckels v. Spreckels, 116 Cal. 339, 48 Pac. 228 (1897); Packard v. Arellanes, 17 Cal. 525 (1861); 2 AMrerican Law of Property \$\$ 7.2, 3 (Casner ed. 1952); Conmy 2-9; McKay, Comarumity Property $\$$ ï̈ (1st ed. 1910); Ogden, California Conarumity Property Law § 4.2 (1956) ; Powell, Community Property-A Critique of Its Regulation of Intra-Family Relations, 11 WASH. L. REv. 12, 26-27 (1936).

In accordance with ordinary principles of international law, this legal system remained in force after California was ceded to the United States in the Treaty of Guadelupe Hidalgo. Estate of Buchanan, 8 Cal. 507 (1857); Fowler v. Smith, 2 Cal. 568, 569 (1852); Kirkwood, Historical Background and Objectives of the Law of Community Property in the Pacific Coast States, 11 WASH. L. REv. 1, 3 (1936). The Treaty of Guadelupe Hidalgo guaranteed that the property rights of Mexicans residing in California would not be affected by the ceding of California to the Umited States. 1 Armrstrong 432; see Commy 5. See also 2 Witron, Sumarary of CaIIfornia Law Real Property \&2 (7th ed. 1960). 
revenue from a spouse's separate property went into the community..$^{32}$ This principle was based on the realization that "most things till touched by the hand of man are wholly unproductive," 33 and the concept that each spouse is primarily interested in the welfare of the community..$^{34}$ The original California constitution, adopted in 1849, included the following clause:

All property, both real and personal of the wife, owned or claimed by her before marriage, and that acquired afterward by gift, devise or descent shall be her separate property; and the laws shall be passed more clearly defining the rights of the wife, in relation as well to her separate property, as to that held in coinmon with her husband.85

The first California legislation dealing with community property followed the Spanish law, and provided that the rents and profits of either spouse's separate property belonged to the community. ${ }^{36}$

In George v. Ransom, ${ }^{37}$ the California Supreme Court, relying on the aforesaid constitutional definition of the wife's separate property, held the legislation invalid with regard to income from the wife's separate estate. ${ }^{38}$ Such income was held to be her separate property. The reasoning of George was that the common law background of the framers of the constitution, coupled with the tendency in common law jurisdictions to recognize the rights of a wife to hold and administer property in her own name ${ }^{39}$ was responsible for the adoption of the constitutional section $^{40}$ in question. Thus, the court held that:

This term "separate property" has a fixed meaning in the common law, and had in the minds of those who framed the Constitution, the large majority of whom were familiar with, and had lived under that system. ... It is not perceived that property can be in one, in fixed and separate ownership, with a right in another to control and enjoy all its benefits. 41

The facts of George presented the court with a situation in which a creditor of the husband was attempting to attach the dividends of stock owned separately by the

32 Estate of Hale, 2 Cof. Prob. Dec. 191, 200 (1906) ; Fuller v. Ferguson, 26 Cal. 546 (1864); Scott v. Ward, 13 Cal. 458, 471 (1859); Loeb, The Legal Property Relations of Married Parties 68 (1900); Schomid, The Civil Law of Spain and Mexico pt. 2, at 13 (1851) (art. 44(2)) ; 1 White, A New Colfection of Laws of Great BritanN, France and SpaIN 61-62 (1839); Loewy, The Spanish Community of Acquests and Gains and Its Adoption and Modification by the State of California, 1 CALIF. L. REv. 32, 40 (1912).

Under Mexican law this principle was defined in the following manner: "Maguer que el marido haya mas que la mujer, $\dot{o}$ la inujer mas que el marido, quier en . . . mueble, . . . los frutos sean coinunes de ambos á dos. . . " Escriche, Diccionario Razonado de Legislacion $Y$ JURISPRUDENCIA 366 (1925).

33 MCKay, CoMMunity Properiy $\& 176$ (1st ed. 1910).

34 DEFUNTAK $\$ 71$ n.43.

35 Cal. Stats. 1949-1950, at 33 (art. 11, §14).

36 Cal. Stats. 1850 , ch. $103,89$.

3715 Cal. 322 (1860).

38 Prior to the decision in George, the statute had been recognized by the court as valid. Snyder v. Webb, 3 Cal. 83, 87 (1853).

${ }^{39}$ See 1 Armstrong 432; Verradx, Cases on Cartrornia Comarunity Property 20 n.47 (1960); Schreter, "Quasi-Community Property" in the Conflict of Laws, 50 CALIF. L. Rev. 206 (1962).

40 See note 35 supra and accompanying text.

$4115 \mathrm{Cal}$. at 324. 
wife. ${ }^{42}$ The court's use of the common law ${ }^{43}$ was apparently influenced by a desire to protect the wife. ${ }^{44}$

The proceedings in the Constitutional Convention do not appear to support the conclusion reached by George. ${ }^{45}$ Although it is not clear what motivated the delegates to adopt the community property system, ${ }^{46}$ by passing the section as it

42 In the Spanish-Mexican system the wife's share of the community property was not hable for the separate debts of the husband. 1 DEFUNIAK $\$ 160$; MARSH, MartTat Property in Conflict of Laws 21 n.27 (1952) ; 2 ThfFany, Real Property \$ 441 (3d ed. 1939). However, in an early case the California Supreme Court used common law principles to determine that the community property was hable for the separate debts of the husband. Van Maren v. Johnson, 15 Cal. 308 (1860). Not grasping the true comnunity property principles involved, 1 DEFUNLAK \$ 162, at 455-57 (see also Evans, Comtmunity Obligations, 10 CALIF. L. REv. 120, 123 (1921)), the court in George turned to the more familiar common law, see 1 ARMSTRong 432 , in order to protect the wife in this situation. See Marsh, MartTal Property IN Conflict OF Laws 20-21 (1952).

In Idaho, the original community property provision that the wife's share of the community property is not liable for the husband's debts is still retained by construing the statute exempting the wife's property from the husband's debts to apply to her half of the community property. IDazo Code ANN. \$\$ 32-906, 11-204 (1948); see JaCoB, Comminnity Property IN IDAHо 37 (1943). In the Scandinavian countries the rents and profits of the wife's separate property belong to the community, but this particular class of community property is not liable for debts of the husband. Loeb, Legal Property Rerations of Married Parties 72 (1900).

43 The use of common law principles to interpret the constitution in George clearly caused a departure from the Spanish-Mexican community property system. 1 DEF UNIAK $\$ 160$; McKAY, Cosmuntty Property \$ 795 (2d ed. 1925); 2 TIFrany, Real Property $\$ 441$ (2d ed. 1939); Clark, New Mexico Community Property Law, in Charmatz \& DagGetr, Comparative Studies IN Commonity Property 81, 96 (1955); Lobingier, The Marital Community: Its Origin and Diffusion, 14 A.B.A.J. 211, 216 (1928).

Ironically, however, it has been pointed out that the use of the common law in George was not in itself entirely correct. Car. JuR. Communnity Property $\$ 39$ n.14 (McMurray Supp. 1930). The courts of equity had recognized the rights of married women at an early date, Ponterox, Equity Jurisprodence 15 (1883); Stewart, Husband and WIfE § 464 (1885); 2 STORY, EQUITY JURISPRUDENCE \& 1367 (9th ed. 1866), but "at common law, without the intervention of equitable interests and principles, the rents of the wife were absolutely the lrusband's property, though her real property was her own," Car. Jur. Community Property $\$ 39$ n.14 (McMurray Supp. 1930); and at common law the husband had the right to the present enjoyment of the wife's property, STEWART, op. cit. supre $\$ 464$. Thus, the common law could actually liave been used to bolster a result more properly reached under the Spanish system, that rents and profits are community property. See 3 Poncroy, EQUTTY JURISPRUDENCE 29 (1883); STEWART, op. cit. supra \$ 470; VerNIER, AMIERTCAN FaMTIIY LAW \$159 (1935); WeLIS, SEParate Property of Marreed Women 165 (1878); Horne, Comnunity Property-A Functional Approach, 24 So. CAL. L. Rev. 42, 45 (1950).

44 Although the court was worried about protecting the wife, it is interesting to note that in the California Constitutional Convention, Mr. Lippitt, arguing for the adoption of the common law, was worried that creditors of the husband would not receive the protection under a community property system that they would under principles of common law. BRowNE, The Debates in the Convention of Caltrornia 262 (1850) [hereinafter cited as Browne].

45 Cax. JuR. Community Property $\$ 39$ n.14 (McMurray Supp. 1930); see BRowne 257-69; Kirkwood, Historical Background and Objectives of the Laws of Community Property in the Pacific Coast States, 11 WASH. L. REv. 1, 4 (1936).

46 During the debates, Secretary of State Halleck of Monterey stated:

I am not wedded either to the Common Law or the Civil Law, nor as yet to a women .... I shall advocate this section in the Constitution, and I would call upon all the bachelors im this convention to vote for it. I do not think we can offer a greater inducement for women of fortune to come to California. It is the very best provision to get us wives that we can introduce into the Constitution.

BROWNE 259. 
was originally proposed the delegates manifested their intention that the community property system should be adopted. ${ }^{47}$ Later cases seemed to accept this as the intention of the framers. ${ }^{48}$ Furthermore, even though most of the justices of the California courts were schooled in the common law, ${ }^{40}$ it was early realized that "our system . . . is borrowed from the civil and Spanish law, and we must look to these sources for ... the rules and principles which govern its operation and effect."50 Thus, it seems clear that the words "separate property" in the California constitution were not intended in their common law sense. ${ }^{\text {t1 }}$

A comparison between the history of the coinmunity property system in Texas with that of California may help to clarify the intent of the framers of the California constitution. In 1840 the Texas Congress decided to retain the Spanish coinmunity property system which had been in force before they gained their in-

47 Stewart v. Stewart, 199 Cal. 318, 249 Pac. 197 (1926); Dow v. Gould \& Curry Silver Mining Co., 31 Cal. 629 (1867); Robbins v. United States, 5 F.2d 690 (1925); 1 DEFUNIAK 51; Cat. Jur. Community Property \$39 n.14 (McMurray Supp. 1930); Kirkwood, supra note 45, at 4; Lobingier, The Marital Community: Its Origin and Diffusion, 14 A.B.A.J. 211, 216 (1928) ; Loewy, The Spanish Community of Acquests and Gains and Its Adoption and Modification by the State of California, 1 CaLIF. L. REv. 32, 33 (1912); McMurray, The Beginnings of the Community Property System in California and the Adoption of the Common Law, 3 CantF. L. Rev. 359, 369-73 (1915); see 1 Schouler, Marrtage, Drvorce and Separation $\S 298$ (6th ed. 1921).

In the convention, Mr. Lippitt, a delegate froin San Francisco, proposed an alternative provision to the one adopted. Browne 257. This provision would have inade it possible to later adopt the common law pertaining to the rights of married persons. Ibid. Mr. Lippitt admitted that he was "wedded to the cominon law," and argued that it was "the law under which ninetenths of the people now in Cahifornia were born and educated." Id. at 260 . The debate in the convention revolved around the question whether the common or civil law should be adopted as the method for determining the property rights of married persons in California. Racouillat v. Sansevian, 32 Cal. 376, 385 (1867) ; BROwNe 257-69; 1 DEFunInK \& 51, at 108; Kirkwood, supra at 3; see Hitchcock, Modern Legislation Touching Marital Property Rights, 6 So. L. REv. N.S. 633,656 (1880).

The Cahfornia constitution provision was copied from the constitution of Texas, see note 53 infra; when this provision was written into the Texas constitution the intent of the Texas framers was to adopt the conmunity property system. Huic, The Texas Constitutional Definition of the Wife's Separate Property, 35 Texas L. REv. 1054, 1055 (1957).

48 In Estate of Moffitt, 153 Cal. 359, 363, 95 Pac. 653, 654 (1908), the court said, "it was the design of the constitution of 1849 to preserve ... to the wives of the inhabitants of the new state ... the rights to the community property which they had enjoyed under the Mexican rule." See Stewart v. Stewart, 199 Cal. 318, 249 Pac. 197 (1926); Roberts v. Wehmeyer, 191 Cal. 601, 218 Pac. 22 (1923); In re Spencer, 82 Cal. 110, 23 Pac. 37 (1889) ("separate property is a relative term; it implies the existence of the coinununity").

401 ARMSTRONG 432.

50 Packard v. Arellanes, 17 Cal. 525, 537 (1861). See also Schuyler v. Broughton, $70 \mathrm{Cal}$. 282, 11 Pac. 719 (1866). But see Dow v. Gould \& Curry Silver Mining Co., 31 Cal. 629 (1867); cf. Van Maren v. Johnson, 15 Cal. 308, 311-12 (1860); Preface, 1 Cal. v, vi (1851).

51 The decision in George v. Ransom has been widely criticized. BaLLivger $\S \S 22,24$; 1 deFuniak $\$ \$ 71$ at 183,51 at 111 ; McKay, Comarunity Property $\$ 288$ (2d ed. 1925); Huie, supra note 47, at 1059; Lobingier, The Marital Community: Its Origin and Diffusion, 14 A.B.A.J. 211, 216 (1928). Making the rents and profits of separate property the separate property of either spouse tends "to enasculate the coinmunity property systein and further a trend toward a systein of separate property in each spouse which may ultimately leave the community property systent one in name only." 1 DEFUNIAK $\$ 72$, at 187. Such deviations from the Spanish-Mexican system should be nuade only after full consideration has been given to the problems which are likely to result. See Hnie, supra at 1059-60. See also Barringer $\$ 24$; McKax, COMCMUNITY Property \& 76, at 161 (1st ed. 1910). 
dependence, ${ }^{52}$ and in 1845 that system was written into the Texas constitution..$^{53}$ The California constitutional provision involved in George v. Ransom ${ }^{54}$ was copied verbatim from this Texas provision..$^{55}$ The California statute ${ }^{56}$ providing that revenue from separate property should inure to the community was also modeled on a Texas provision..$^{57}$ In 1917 the Texas legislature, following California's lead in George, ${ }^{58}$ changed their law to provide that the rents and profits of separate property should remain separate. ${ }^{59}$ However, the Supreme Court of Texas, in Arnold v. Leonard,$^{60}$ held this statute to be unconstitutional. The court said that the constitution was exclusive; the only property acquired after marriage that could become the separate property of the wife was property acquired by "gift, devise or descent." 61 Thus, the rents and profits of separate property were held to belong to the community. ${ }^{2}$

The decision in George v. Ransom had no effect on the profits of the husband's property because his rights to hold property separately were not guaranteed in the constitution until $1879 .{ }^{63}$ The court in Lewis $v$. Lewis ${ }^{64}$ held that the rents and profits of the husband's separate property belonged to the community in accordance with the Act of $1850 .{ }^{65}$ In 1872 , however, the legislature, influenced by George ${ }^{60}$ made the rents and profits of either spouse the separate property of that spouse. ${ }^{67}$ Inasmuch as the statutes of most of the other conmunity property

52 Early Laws of Texas 334 (1888); see Burnetr, Comamunity Property Law 40 (1926); Huie, The Community Property Law of Texas, 13 Tex. Rev. Crv. Stat. ANv. 1 (1960). 53 Burnetr, Comarunity Property Law 40 (1926) ; Huie, supra note 47, at 1055.

54 See note 37 supra and accompanying text.

55 Selover v. American Russian Commercial Co., 7 Cal. 266, 270 (1857) ; BaLLINGer § 22 ; McMurray, The Beginnings of the Community Property System in California and the Adoption of the Common Law, 3 CALIF. L. REv. 359, 373 (1915). But see McMurray, Seventy-Five Years of California Jurisprudence, 13 CaLIF. L. Rev. 445, 453 (1925).

66 Cal. Stats. 1850 , ch. 103, \&9.

57 Kirkwood, Historical Background and Objectives of the Law of Community Property in the Pacific Coast States, 11 WASH. L. REv. 1, 4 (1936).

58 McKay, CoAmurumtr Property $\$ 287$ (2d ed. 1925).

59 Tex. Gen. Laws 1917, ch. 194, at 460.

co 114 Tex. 535, 273 S.W. 799 (1925).

61 Id. at 539-40, 273 S.W. at 801; see Goodrich, Conflict of Laws $\S 122 \mathrm{n} .8$ (3d ed. 1949). In Washington such legislation was upheld. See cases cited in Evans, Primary Sources of Acquisition of Community Property, 10 CALIF. L. REv. 271, 277 (1922).

62 It has been suggested that the framers of the California constitution similarly intended to place the Spanish system beyond the reach of the legislature. BuRNETr, Comarounity PropERTY LAW 41 (1926); 1 DEFUNIAK $\S 51$. Mr. Burnett takes the position that the constitution recognized rather than adopted the system as existing in Cahfornia, and the direction to the legislature in the last part of the section was intended to mean that the legislature should define the rights of the wife in the cominumity property in accordance with Mexican Law. There was no authority, however, to change the existing community property system in any way. BURNETT, op. cit. supra at 40-43. But cf. McMurray, Seventy-Five Years of California Jurisprudence, 13 CAITF. L. Rev. 445 (1925).

03 Cal. Stats. 1880, at liv (art. XX, §8).

6418 Cal. 654 (1861).

65 See BaLLnnger $\$ 22$; Evans, Primary Sources of Acquisition of Community Property, 10 CaIr. L. Rev. 271, 277 (1922); MeMurray, Community Property, 5 CaI. JuR. 268 (1922).

661 The Calmornia Fammly Lawyer 114 (Cont. Ed. Bar 1962); Huie, supra note 47, at 1058 n.25; see Conary 12; McKay, Conmunity Property $\$ 287$ (2d ed. 1925).

o7 CAL. Crv. CODE $\$ \S 162,163$. 
states $^{68}$ are modeled on the California code, ${ }^{69}$ the decision in George was thus directly responsible for introducing this novel treatment of the rents and profits of separate property to the American law of community property. ${ }^{70}$

\section{B. Initial Problem of Whether To Apportion}

It having been decided that rents and profits of separate property are not community property, there arose the problem of determining the character of income from a separate property business where one of the spouses actively participated in the business during the marriage period. This problem was not considered in George v. Ransom, since in that case the income produced did not involve the efforts of either spouse.

Just as the court's desire in George to protect the wife's property was responsible for the creation of the problem, ${ }^{71}$ the same motivation influenced the early attempts to solve it. ${ }^{72}$ The first cases arising after George concerned the attempts of an assignee ${ }^{73}$ or creditor of the husband ${ }^{74}$ to reach the profits of the wife's separate property. ${ }^{75}$ The courts, influenced by the desire to protect the rights of women, ${ }^{76}$ took the view that "one object of the [constitutional] provision ${ }^{77}$ was to protect the wife against the improvidence of the husband."78 Accordingly, all the income was held to be the separate property of the wife, ${ }^{79}$ thereby protecting what were felt to be her property rights. ${ }^{80}$ In order to reach this result, the courts had to disregard the effort and labor of the husband as factors in the production

68 Artz. Rev. Stat. ANN. \$\$ 25-211, -213 to -214 (1956); Nev. Rev. Stat. $\$ \$ 123.130, .220$ (1957) ; N.M. Stat. ANn. \$§ 57-3-4, -6, -4-1 (1953) ; WASH. Rev. COdE $\$ \$ 26.16 .010, .020, .030$ (1961).

692 american Law of Property \$7.3 (Casner ed. 1952); Batlinoer \$24; Huin, Texas Cases on Marttal Rughts 212 (1955); McKay, Comarunity Property § 6 (2d ed. 1925); VERNIER, AMERICAN FaMIIIY Laws 207-08 (1935); Kirkivood, Historical Background and Objectives of the Law of Community Property in the Pacific Coast States, 11 WASH. L. Rev. 1, 8 (1936); LeSourd, Community Property Status of Income from Business Involving Personal Services and Separate Capital, 22 WASE. L. REv. \& ST. B.J. 19, 21 (1947); Lyons, Development of Community Property Lawe in Arizone, in Charmatz \& Daggetr, Comparative Studies in Comomunity Property 3, 5 (1955).

70 McKaX, Community Property $\$ 287$ (2d ed. 1925); see id. $\$ v$ (1st ed. 1910).

71 See note 44 supra and accompanying text.

72 LeSourd, supra note 69 , at 22.

i3 See, e.g., Diefendorff v. Hopkins, 95 Cal. 343, 28 Pac. 265 (1891).

74 See, e.g., Lewis v. Johns, 24 Cal. 98 (1864).

75 Walsh v. Walsh, 84 Cal. 101, 23 Pac. 1099 (1890); Diefendorfi v. Hopkins, 95 Cal. 343 , 28 Pac. 265 (1892) ; Peck v. Brummagim, 31 Cal. 440 (1866); cf. Davis v. Green, 122 Cal. 364, 55 Pac. 9 (1898).

${ }^{76}$ See Hitchcock, Modern Legislation Touching Marital Properly Rights, 6 So. L. REv. N.S. 633, 634 (1880); LeSourd, supra note 69, at 22.

77 See text accompanying note 35 supra.

78 Lewis v. Johns, 24 Cal. 98, 101-02 (1864), quoting from George v. Ransom, 15 Cal. 322 (1860).

79 To the same effect were the decisions of the Washington Supreme Court holding that the commumity derived no interest in the income from a separate property business by reason of the effort and skill of the spouses. See Hester v. Stine, 46 Wash. 469, 90 Pac. 594 (1907); Brookman v. State Ins. Co., 18 Wash. 308, 51 Pac. 395 (1897); Leake v. Hayes, 13 Wash. 213, 43 Pac. 48 (1895); LeSourd, supra note 69, at 22 n.19.

80 In Spear v. Ward, 20 Cal. 659 (1862), the creditors of the husband were held not entitled to the products of the wife's separate property farm, even though the wife had executed a crop mortgage in their favor. The court held that the wife was merely a surety for the husband's debt. 
of the profits. ${ }^{81}$ When cases involving the rents and profits of the husband's property later arose, the courts, to remain consistent, held the entire proceeds to be his separate property. ${ }^{82}$

The first consideration given to the factor of a spouse's skill or effort in operating a separately owned business was in the Nevada decision in Lake v. Bender. ${ }^{83}$ This case, rather than considering an apportionment, looked at the various factors only to determine whether or not the sum in dispute came within the definition of rents and profits. The court held that where the separate property itself was a more important factor than the skill of the husband in the production of the income from a hotel and ranch, ${ }^{84}$ the entire income from the business constituted rents and profits of the separate property. The community was not permitted a share in the profits. Lake differed from previous cases, however, in that it recognized that the skill of the spouses had been instrumental in the production of the income. ${ }^{85}$ Furthermore, the court stated in a dictum that "if profits come mainly from the efforts or skill of one or both, they belong to the community." 86

In an article criticizing the Lake case, Professor Pomeroy expressed doubt that the income from a commercial enterprise was intended by the legislature to constitute rents and profits. ${ }^{87} \mathrm{He}$ also pointed out that the decision in Lake furnished no real test to determine which interest in the property should predominate. This inadequacy was recognized in Lake itself, the court stating that "it may be difficult in a given case to determine the controlling question, owing to the equality of the two elements mentioned, but we know of no other method of determining to whom the profits belong." 88 Apportionment simply was not considered.

In finding the entire amount to be separate property, the court in Lake found support in cases from common law jurisdictions holding that the profits from a business or farm that were the separate property of the wife could not be reached by the creditors of the husband, even though he had participated in operating the business. ${ }^{80}$ Since the common law courts would not allow the creditors to reach the profits on the basis of the husband's participation, it was analogized that no part of the profits could be allocated to the community on the basis of the huband's skill and effort.

81 The language used in Lewis v. Johns, 24 Cal. 98, 102 (1864), is typical of the court's attitude: "the husband cannot, by any independent act of his, acquire an interest in the separate estate of the wife."

82 Estate of Granniss, 142 Cal. 1, 75 Pac. 324 (1904) ; Estate of Cudworth, 133 Cal. 462, 65 Pac. 1041 (1901); Estate of Higgins, 65 Cal. 407, 4 Pac. 389 (1884). But cf. Estate of Bauer, 79 Cal. 304, 21 Pac. 759 (1889).

It is ironical that this desire to protect the wife's property rights should result in a situation where "her only chance to acquire by marriage any interest in property is to marry a man who has nothing, with the hope that he may afterwards earn something in which she will have a community right." Estate of Cudworth, supra at 469, 65 Pac. at 1044 (concurring opinion). See Pomeroy, Husband's Separate Estate, 4 WEST COAST RPTR. 193, 195 (1884).

8318 Nev. 361 (1884).

84 In Lake, the wife had also worked in the hotel during the entire period of marriage.

85 In earher Califorma cases it was contended that the effort and skill of the spouses should have the effect of making the profits community property. See, e.g., Lewis v. Johns, $24 \mathrm{Cal}$. 98, 100 (1864). But the doctrine of George v. Ransom was felt to preclude such a holding. Id. at 102.

${ }^{80}$ Lake v. Bender, 18 Nev. 361, 392 (1884). See LeSourd, supra note 69, at 23.

87 Pomeroy, supra note 82 , at 196 , suggesting that the husband's estate be credited with the average rate of interest or the fair rental value in these circumstances.

$8818 \mathrm{Nev}$. at 392 .

80 Id. at 387 . 
The Lake case was important in three ways in shaping the early law concerning the disposition of the income from separate property businesses. ${ }^{.0}$ First, the case became the accepted authority for the black letter rule ${ }^{01}$ that the profits would be separate property if the predominant factor in their production was the capital, but would be community if the effort of one of the spouses had been more instrumental..$^{92}$ Second, the Lake case pointed up the injustice of allocating the entire profits to either the community or the separate estate. ${ }^{03}$ Perhaps the greatest influence of $L a k e$, however, was in the example the court set by analogizing this community property problem to the common law problem involving creditors of the husband seeking to seize the revenue of the wife's business or farm..$^{94}$ It was the use of similar unsound analogies that led to the creation of the apparent inconsistency between Pereira v. Pereir ${ }^{05}$ and Estate of Pepper. ${ }^{03}$

Another way in which the courts approached the problem before the idea of apportionment was first crystalized was to consider the income as a commingled fund. The decision of the Supreme Court of Washington in In re Buchanan's $E_{\text {state }}{ }^{07}$ typifies this approach. ${ }^{98}$ The court held the profits of the separate investment to be so commingled with community earnings as to make the mcome from the business during ten years of marriage entirely community property. ${ }^{00}$

Although the results differed, the Lake and Buchanan cases were both decided on the principle that the character of the property is determined by deciding which

90 Even today remnants of the Lake rule are found in California apportionment cases, in that the relative importance of the capital or the personal services as factors in the production of income may bear on what apportionment is made or whether the entire amount of the profits are allocated to the separate estate. See Estate of Neilson, $57 \mathrm{Cal} .780,787,371$ P.2d 733, 736, 22 Cal. Rptr. 1, 5 (1962).

91 McKay's statement in 6 AMr. \& ENG. ENCX. LAw 324 (1898), was particularly influential, as it was frequently cited by counsel as the "rule" of the Lake case. See Respondents Brief, pp. 106-07, Pereira v. Pereira, 156 Cal. 1, 103 Pac. 488 (1909); Appellant's Points and Authorities, pp. 1, 22-23, Estate of Pepper, 158 Cal. 619, 112 Pac. 62 (1910). Despite the fact that the statutes of all the community property states were different, the treatises were all written in generalizations. See, e.g., 21 Cyc. 1648 n.56 (1906).

92 McKay also stated the Lake case as a rule in his treatise, McKay, Comomunity PropERTY $\$ 76$ (1st ed. 1910), as did Judge Ballinger, Baxlinger \$ 24, and Professor Pomeroy, Digesh of Cases, 4 WEST COAST RPTR. 765, 858 (1884).

03 McKay realized that the rule of the Lake case, on its face, confessed an injustice to either the separate estate or the community. McKay, CoNSMIUNITY PROPERTY $\$ 313$ (2d ed. 1925).

94 In Lake the court said, "most of the cases to which we shall refer upon this question inolve [sic] the right of a wife to claim profits arising from the use of her separate estate, as against the creditors of the husband, when they have been increased by his labor and skill." $18 \mathrm{Nev}$. at 387.

95156 Cal. 1, 103 Pac. 488 (1909).

$96158 \mathrm{Cal} .619,112 \mathrm{Pac} .62$ (1910). See text following notes 111 and $183 \mathrm{infra}$.

9789 Wash. 172, 154 Pac. 129 (1916).

08 Apportionment had been made earlier in Pereira, see text accompanying notes 9-10 sutpra, but the Washington courts refused to apply this rule, LeSourd, sicpra note 69 , at 25-26. In California, the commingling approach had been used both before Pereira, Estate of Bauer, 79 Cal. 304, 21 Pac. 759 (1889), and after, Estate of Fellows, 106 Cal. App. 681,289 Pac. 887 (1930).

9089 Wash. 172, 179-80, $154 \mathrm{Pac} .129,132$ (1916). In finding the income to be community property, the court relied on Lake v. Bender as well as on the line of conmon law cases, rejected in Lake, that had allowed the creditors to reach the income from the wife's separate property on the basis of the personal service he had devoted to that property. See text accompanying note 89 supra. Compare the use of Glidden v. Taylor, 16 Ohio St. 510 (1866), in Lake v. Bender, 18 Nev. 361, 393 (1884), with its use in In re Buchanan's Estate, 89 Wash. 172, 181, 154 Pac. 129, 132 (1916). 
of two factors, the capital or the skill of one of the spouses, was more important in the production of the income. ${ }^{100}$ The Nevada court in Lake found that the capital was the primary factor in the production of the profits, whereas the Washington court in Buchanan found the skill of the spouses a more important factor. The importance of the Buchanan case lies in the additional step to the Lake approach, in that once it was found that the profits were primarily community, the concept of commingling was further used to justify holding the entire sum allocable to the community. ${ }^{101}$

\section{II}

\section{BEFORE Neilson}

\section{A. Pereira v. Pereira}

The first decision apportioning profits in a community property state was Pereira v. Pereira. ${ }^{102}$ The trial court found that the proceeds from the husband's separately owned cigar store-saloon were all community property. Mr. Pereira appealed, claiming that the entire proceeds should be his separate property because they were the rents and profits of his separate property. ${ }^{103}$ This contention was supported by the early California cases ${ }^{104}$ that had not considered the skill of either spouse as a factor in the production of income. ${ }^{105}$ Mrs. Pereira, relying mainly on the dictum in Lake v. Bender, ${ }^{106}$ argued that the entire proceeds should be community property, ${ }^{107}$ since the evidence had shown the husband's skill to be the main factor $\mathrm{m}$ producing the mcome. ${ }^{108}$ To further support this contention

${ }^{100}$ Although the Washington court treated the fund as commingled, the implication was that if the capital invested was more important than the services of the spouse the entire fuud would be separate. 89 Wash. at 179-81, $154 \mathrm{Pac}$. at 132. The cases relied on in Lake did not allow creditors of the husband to seize the income of the wife's separate property, but the cases relied on in Buchanan allowed the proceeds to be reaclied in certain circumstances. See notes 118-21 infra.

101 The problem is often still treated in terms of a commingled fund. Ormachea v. Ormacliea, 67 Nev. 273, 217 P.2d 355 (1950); Burby \& Patiy, Selected Problems nn Communty Property and Domestic Relations 12 (1958); Kende, Commounity Property law in Arizona 15 (1958); McKay, Comarunity Property $\$ 317$ (2d ed. 1925); Cross, The Communily Property Law in Washington, in Chardatz \& Daggett, Comrparative Studies in Comarunity Property 150, 162-66 (1955); see Porter v. Porter, 67 Ariz. 273, 195 P.2d 132 (1948); Jacobs v. Hoitt, 119 Wash. 283, 205 Pac. 414 (1922). See also In the Matter of Estate of Torrey, 54 Ariz. 369, 95 P.2d 990 (1939).

The problem is also analagous to situations where separate and community funds are used to buy land or when community property is used to improve separate property, and vice versa. 4 Poweli, Real Property 685 (1954); Comment, 50 Calfe. L. Rev. 844 (1962).

102156 Cal. 1, 103 Pac. 488 (1909).

103 Opening Brief of Appellant, pp. 30-31.

104 See cases cited note 82 suppra.

105 Opening Brief of Appellant, pp. 26-31.

106 See text accompanying note 86 supra.

107 Brief for Respondent, pp. 102-07.

108 The record includes the following:

Q. Of course that is an enormous profit Mr. Pereira on that amount of money.

I suppose it is due to your individual efforts?

A. I judge it is ....

The Court. Mr. Pereira, it is due to your own efforts you made this money?

A. Yes, sir, hard labor day and might.

Transcript on Appeal, pp. 102-04. 
she cited common law decisions involving attempts of the husband's creditors to reach the profits of a business operated by the husband with capital belonging to his wife. ${ }^{109}$

Pereira was argued by both sides on the assumption that the profits were either entirely community property or entirely separate. ${ }^{110}$ Nevertheless, it was held that unless the contrary could be shown, it must be assumed that the separate property investment was responsible for part of the profits, and that this share would at least amount to the interest rate on a long-term investment, with the remainder being held community property. ${ }^{111}$

\section{The Rationale Behind Pereira}

To support the holding that an apportionment should be made, measured by the interest rate on a well secured investment, Pereira, like Lake, ${ }^{112}$ drew analogies from common law creditor cases. ${ }^{113}$ Each of the cases cited had been decided during a period when the recognition of a married woman's right to hold property and transact business in her own name ${ }^{114}$ was new to the common law, ${ }^{115}$ and when there was much confusion in handling the problems created by these new rights. ${ }^{110}$ As a result of such recognition, a debt-ridden husband was afforded an opportunity to run his wife's business while denying his creditors recourse to the business income. The courts thus were confronted with the problem of protecting the wife in accord with the statutes, yet preventing the husband from defrauding his creditors. ${ }^{117}$

In most instances the income from the wife's business was held to belong to

109 Brief for Respondent, pp. 107-13.

110 Oral Argument of J. F. Bowic on Behalf of Respondent, pp. 9-14; Oral Argument of Myer Jacob on Behalf of Appellant, pp. 19-21.

It appears as though counsel for Mrs. Pereira thought that opposing counsel was arguing for at least some of the earnings to be separate property. Brief for Respondent, p. 117. It would seem, however, that counsel for Mr. Pereira was only claiming that part of the piece of property in question was bought with separate funds other than those earned in the business, and was not secking a division of the earnings. Opening Brief of Appellant, pp. 31-32.

111 The court stated that "in the absence of circunstances showing a different result, it is to be presumed that some of the profits were justly due to the capital invested. There is nothing to show that all of it was due to defendant's efforts alone. The probable contribution of the capital to the income should have been determined from all the circumstances of the case, and, as the business was profitable, it would amount at least to the usual interest on a long investinent well secured." $156 \mathrm{Cal}$. at 7, $103 \mathrm{Pac}$. at 491.

112 See text accompanying notes 89 and 94 supra.

113 Boggess v. Richards, 39 W. Va. 567, 20 S.E. 599 (1394); Trapnell v. Conklyn, 37 W. Va. 242, 16 S.E. 570 (1892); Penn v. Whitehead, 17 Gratt. 503, 94 Am. Dec. 478 (1367); Ghiden v. Taylor, 16 Ohio St. 509 (1866). Neither Penn nor Trapnell appear in the briefs of either party discussing the community property issue. See Opening Brief of Appellant, pp. 25-32, Brief for Respondent, pp. 103-20, Reply Brief for Appellant, pp. 60-79.

114 See StewART, HUSBAND AND WIFE $\S 184$ (1885). Although a married woman's ability to administer her property was especially restricted by the fact that she could not, at common law, contract in her own name, this restriction was also lifted by statute. See ANson, CoNTRACTS 234-36 (1939); WHITNEY, CoNTRACTS § 11, at 10 (1958).

115 Schouler, Domestic Relations \& 164 (5th ed. 1895); Hitchcock, Modern Legislation Touching Marilal Property Rights, 6 So. L. REv. N.S. 633 (1380).

116 Parsons, Law of Partwership 24 (1867); Schouler, Domestic Relations 9-10 (2d ed. 1874).

117 See Schouler, Domestic Retations $\S 168$ (5th ed. 1895); id. at 19-20 (2d cd. 1374). 
her, notwithstanding the husband's skill and effort involved.118 Nevertheless, where the husband had acted with an obvious intent to defraud his creditors, the courts would look behind the form of the transaction and protect the creditors where the equities warranted it. ${ }^{119}$ In such instances the courts generally held that the business really belonged to the husband, and that his creditors could reach its entire incoine. ${ }^{120}$ Where the fraudulent nature of the transaction was less evident, the courts would find that part of the proceeds constituted rents of the wife. But the courts then reasoned that since she had allowed the rents to become commingled with the earnings of the husband, the creditors should not be prejudiced and could satisfy their debts from the entire incoine. ${ }^{121}$ The rationale was that the wife could have prevented the commingling, whereas the creditors were powerless to do anything and should not be made to suffer a loss. ${ }^{122}$

In cases where the wife did not partake in the fraud, some of the equity courts

118 In Boggess v. Richards' Adm'r, 39 W. Va. 567, 574, 20 S.E. 599, 602 (1894), the court said:

It has been settled by numerous and repeated decisions that it matters not how much of his labor and skill a man may devote to his wife's property; and, although it may be changed from a rude to a manufactured state, it remains her property still, and can not be levied on by execution or attached for his debts.

Citing Atwood v. Dolan, 34 W. Va. 563, 12 S.E. 688 (1890); Miller v. Peck, 18 W. Va. 75 (1881). See Scott v. Hudson, 86 Ind. 286 (1882); Hearts v. Klinnkhammar, 39 Mimn. 488 (1888) ; Coddington v. Bowen, 53 N.Y. (Hun.) 631 (1889); Atwood v. Dolan, 34 W. Va. 563, 12 S.E. 688 (1890); 1 Freeman, Executrons 566 (3d ed. 1900); STEWART, Husband and WIfE $\$ 477$ (1885). See also 3 PoMreroy, Equity Jurrsprudence 24 (1881).

119 See, e.g., Wortman v. Price, 47 Ill. 22 (1868); 1 Schouler, Marriage, Divorce and Separation § 313 (6th ed. 1921); Stewart, Husband and WIFE $§ 469$ (1885); Wells, Separate Property RIGHTS OF WoMren 195-96 (1878). The theory of the courts in those instances where the creditors were allowed to seize the profits was either that the husband had attempted to make a fraudulent conveyance of his services to the wife, BUMr, FraUdULENT Conveyances 263 (4th ed. 1896), that the wife had merely put her money in the husband's business, Annot., 77 Am. St. Rep. 92 (1899), or that the husband had carried on the busimess in his own name without revealing he was the agent of the wife, ScHouter, DOMEstic ReIarrons $\$ 168$ (5th ed. 1895).

120 Busip, Fraudulent Conveyances 262-63 (4th ed. 1896) ; Schouler, Domestic ReIatrons $\$ 168$ (5th ed. 1895); Schouler, Marriage, Divorce aNd Separatron $\$ 313$ (6th ed. 1921); Annot., 77 Am. St. Rep. 92, 101 (1899); cf. Ghdden v. Taylor, 16 Ohio St. 509 (1866). There was more of a reluctance to find that the product of a wife's farm could be reached by the husband's creditors because of the notion that crops arising naturally from the soil remain separate property. See Lake v. Bender, 18 Nev. 361, 395-400 (1884) (dissenting opinion); BUArP, op. cit. supra at \$\$ 224-25; 1 FreEMrAN, EXecutions 566 (1900); Annot., 77 Am. St. Rep. 92, 97-100, 100-09 (1899). Some cases distinguished between the situations where the husband rents the farm and where he is the wife's agent. In the latter case the rents and profits cannot be seized. WeIxs, Separate Property Rrgets of Married Woman 172 (1878).

121 Buns, Fraudutent Conveyances 262 (4th ed. 1896); 1 Schouler, Marriage, Divorce and Separation \$326 (6th ed. 1921); Stewart, Husband and Wife \$§ 129, 311 (1885).

122 Quidort v. Pergeax, 18 N.J. Eq. 472 (1867) ; see Glidden v. Taylor, 16 Ohio St. 509, 521 (1866). The party responsible for commingling a fund is treated similarly in other branches of the law. See Bogert, Trusts $\$ 100$ (3d ed. 1952); Brown, Personal Property \$§ 30-36 (1936). In commumity property states a fund consisting of an uncertain amount of commumity property and separate property is treated as belonging entirely to the community. See Falk v. Falk, 48 Cal. App. 2d 762, 120 P.2d 720 (1941); note 314 infra. Part of the rationale for this treatment is that the husband has control of community property and where he allows it to become so mixed with his own funds that the amount belonging to the community cannot be determined he must suffer the loss. Pope v. Pope, 102 Cal. App. 2d 353, 227 P.2d 867 (1951); 1 DEFUNIAK $\S 61$. 
tried to help her ${ }^{123}$ even though they found the transaction to be fraudulent. ${ }^{124}$ Boggess v. Richards' Adm'r $r^{125}$ and Glidden v. Taylor, ${ }^{128}$ two of the cases relied upon in Pereira, were of this nature. In Boggess, the money that constituted the wife's investment had originally been given to her by the husband before marriage. After the husband became insolvent he used the money to establish a profitable business. In allowing the creditors of the husband to reach these assets the court was strongly motivated by the fraudulent nature of the entire transaction, ${ }^{127}$ but since the wife had not taken an active part in the fraud, ${ }^{128}$ she was allowed her original investment plus the legal interest rate. ${ }^{129}$ The facts in Glidden were very similar, and the court, in effect, found the transaction to be a loan of money from the wife to the husband. ${ }^{130}$ By analogy it was held that the wife was a creditor of the husband, and as such, entitled to her original investment plus interest. ${ }^{131}$ It was from the suggestions in Glidden and Boggess that the California court probably obtained the method of apportionment used in Pereira. ${ }^{132}$ Since the common law courts allowed the creditors to reach the profits of the business as a result of the husband's skill and talent, the California court reasoned that the community was entitled to the profits for the same reason, ${ }^{133}$ Although this was the same type of analogy used in Buchanan, ${ }^{134}$ the California court went even further and

123 Schouler, Domestic Relations \$165 (5th ed. 1895); Wells, Separate Property RTGHTS OF MARRIED WOMAN 195-96 (1876); see 2 StORY, EQUTTY JURISPRUDENCE §§ 1372a-b (9th ed. 1866).

124 This was the result reached in Glidden v. Taylor, 16 Ohio St. 509 (1886). See text accompanying note 130 infra.

12539 W. Va. 567,20 S.E. 599 (1894).

12616 Ohio St. 510 (1866).

127 One writer warned against relying on Boggess as autliority for the proposition that the application of the liusband's services subjected the profits of the wife's separate property to the creditors of the liusband because of the extremely fraudulent nature of the transaction. 1 FrEEMAN, Executions 568-69 (1900). In Deere v. Bonne, 108 Iowa 281, 79 N.W. 59 (1899), the court distinguished Glidden on the grounds that the husband had controlled the wife's property absolutely.

128 Although the wife was not guilty of any actual fraud, the court found that "her hand be it ever so chaste is polluted by receiving as a gift from her liusband the funds whicls he is endcavoring to fraudulently conceal ... from the searching eyes of his creditors." Boggess v. Richards, 39 W. Va. 567, 576, 20 S.E. 599, 602 (1894).

129 "The only way that the law furnislies for the ascertainment of low much of this handsome profit is due to the skill and labor of the liusband is to deduct therefrom the legal interest on the amount of capital invested." Ibid.

130 The court recognized that a wife could not be a creditor of the liusband at common law, but concluded that, since this was an action in equity to divest her of title, she was entitled to protection. Glidden v. Taylor, 16 Ohio St. 509, 522 (1866). See also 2 STOREY, Equiry JURISPRUDENCE \& 1373 (9th ed. 1866).

131 In Trapnell v. Conklyn, 37 W. Va. 242, 16 S.E. 570 (1892), and Penn v. Whitehead, $58 \mathrm{Va}$. (17 Gratt.) 503, $94 \mathrm{Am}$. Dec. 478 (1867), it was mentioned that equity would make an apportionment in a proper case, but none was made.

132 The language used by the court in Pereira was the same language that was used in Glidden. It has also been suggested that the Pereira apportionment rule was abstracted from the Boggess case. Evans, Primary Soutres of Acquisition of Community Property, 10 CaLIF. L. REv. 271, 281 n.78 (1922).

133 In an earlier case the Cahifornia Supreme Court, recognizing the skill and talent of the husband as a factor in the production of income, found the entire amount to be community property under the rationale that the profits constituted a commingled fund. Estate of Bauer, 79 Cal. 304, 21 Pac. 759 (1889).

134 See notes 99 and 100 supra and accompanying text. 
allowed the husband's separate estate the interest on his investnent just as the common law court had allowed this to the wife. ${ }^{\mathbf{1 3 5}}$

Apart from the lack of any rational basis for interpreting a community property problem by common law principles, ${ }^{136}$ sound reasons appear why the Boggess and Glidden cases should not have been relied on by the Pereira court. The married women's property acts were a new innovation in the common law, ${ }^{137}$ and the statutes of various states differed. ${ }^{138}$ Cases froin one common law state were not sound precedent for another such jurisdiction, ${ }^{\mathbf{1 3 9}}$ much less for a coinmunity property state. ${ }^{140}$ Furthermore, the legal relationships involved were not analogous. In community property states a wife cannot force her spouse to labor, ${ }^{141}$ as neither can creditors in common law states. ${ }^{142}$ If, however, the husband chooses to work, the implications are different. The husband's skill is an asset of the community, ${ }_{2}^{143}$ and when he exercises it the resulting product automatically must be considered community property. ${ }^{144}$ In comparison, the common law creditors have no such

135 Since the common law courts held that the wife's capital could only be credited with some type of interest rate, and that the creditors could reach the remaining income on the theory that the husband's efforts had produced it, the California court held by analogy that the husband's capital was only entitled to interest, and that the community was entitled to the rest of the profits because they must be similarly treated as the product of his skill.

1361 deFuniaK § 51, at 110; see Daggett, The Conamunity Property System of LouisiANA 3 (1931).

137 See note 115 supra and accompanying text.

138 STEWART, HUSBAND AND WIFE $\$ 464$ (1885); Hitchcock, Modern Legislation Touching Marital Property Rights, 6 So. L. REv. N.S. 633, 634 (1880). In sone states the only provision was one entitling the wife to hold property; since these statutes were not construed as giving the authority to trade in her own nane, the rents and profits belonged to the husband in the same manner as they had at comnion law. STEWART, op. cit. supra $\$ \$ 464,470,473$; Annot., 77 Am. St. Rep. 92, 100 (1899). In soine states the wife was allowed to trade in her own name with permission of her husband, but, if the arrangement appeared fraudulent, the husband's creditors could reach the profits. STEWART, op. cit. supra $\$ 469$.

139 Stewart, Husband and WIFE $\S 464$ (1885); Annot., 77 Am. St. Rep. 92 (1899). As was the case with community property states, one of the reasons for the confusion in common law jurisdictions was the reliance on treatises and encyclopedias which treated the laws of all jurisdictions without differentiating them. See note 91 supra.

140 Inasmuch as the holdings of the four comnion law cases cited by Pereira were that the creditors of the husband could reach the profits of a business owned by the wife, their use by California courts seems particnlarly strange; it was the desire to protect the wife against just such creditors that was responsible for the original departure from the Spanish-Mexican systen in George. Evans, Primary Sources of Acquisition of Community Property, 10 CaLIF. L. REv. 271, 281-82 (1922); see notes 42 and 44 supra. Cahiforma bas expressly rejected the holdings of these common law cases, both before Pereira, see Lewis v. Johns, 24 Cal. 98 (1864), and after, see Gray v. Perlis, 76 Cal. App. 511, 245 Pac. 221 (1926).

141 Spreckles v. Spreckles, 172 Cal. 775, 158 Pac. 537 (1916). See also CAL. CIv. Code $\$ 156$ (the husband chooses the mode of living).

142 In Penn v. Whitehead, 58 Va. (17 Gratt.) 503, 528, 94 Am. Dec. 478, 494 (1867), the court stated: "[T] he law cannot, or does not, compel a man in advance to labor for his creditors." See Bump, Fraudulent Conveyances § 225 (4th ed. 1896); 1 Freeman, ExecuTIONS 567 (1900).

143 Strohm v. Strohm, 182 Cal. App. 2d 53, 62, 5 Cal. Rptr. 884, 889 (1950); Cross, The Comnunity Property Law in Washington, in Characatz \& DaggetT, Comparative Studies IN Conaronity Property Law 150, 164 (1955); McKay, Conamunity Property \$ 76, at 161 (1910); Wood, The Comanunity Property Law of New Mexico § 39 (1954); Comment, 36 TexAS L. REv. 187, 192 (1957).

1443 Vernier, Aurerican Famier Laws 214 (1931). But see Gray v. Perlis, 76 Cal. App. 511, 245 Pac. 221 (1926), where the value of the husband's labors in the wife's separate property business were held not reachable by creditors of the community. 
lien on the husband's services, ${ }^{145}$ and the husband's earnings are not necessarily subject to their claims. ${ }^{146}$ Thus, the reasons for granting or denying recovery to a creditor in a common law case were not founded upon the same rationale that entitles the community to an interest in the profits under California law. ${ }^{147}$ Still further, the word "apportionment" was not used by the common law courts in the same sense of an attempt to determine the respective shares of the community and the separate estate. As the Glidden case shows, no attempt was made to determine the true relationship between the wife's capital and the husband's services in the production of the income. ${ }^{148}$ The idea of "apportioning" served only to protect the wife from the husband's creditors to whatever extent possible. ${ }^{140}$

\section{The "Rule" of Pereira}

Despite its unsound origin ${ }^{150}$ and the vagueness of its terms, ${ }^{151}$ the use in Pereira of "the usual interest on a long investment well secured" 152 has been taken by many writers to be a rule of law, ${ }^{153}$ and is frequently applied by the courts as a mathematical formula to apportion profits from a separately owned business. ${ }^{154}$ The language used in $M c D u f f$ v. $M c D u f f^{155}$ illustrates how the courts have come to regard the Pereira holding:

It has been held that the proper method of determining the value of a husband's interest in a business in which he was engaged at the time of his marriage is to allow the usual interest to the husband on the amount invested on the basis of a long investment, well secured. ${ }^{156}$

145 Abbey v. Deyo, 44 N.Y. 343 (1871) ; Heckinger v. Swank, 78 Ore. 526, 153 Pac. 784 (1915); 1 FreEMAan, EXEcutions 565-66 (1900); Annot., 77 Am. St. Rep. 92 (1899); see Annot., 28 A.L.R. 1046, 1048 (1924). See also Gray v. Perlis, 76 Cal. App. 511, 245 Pac. 221 (1926).

146 "A debtor may therefore bestow his skill and labor upon his wife's estate so far as may he reasonably necessary, without rendering the products liable to lis creditors." BuMP, Fraudulent Conveyances \$ 225, at 264 (4th ed. 1896). In Trapnell v. Conklyn, $37 \mathrm{~W}$. Va. 242,16 S.E. 570 (1892), the court stated that the fact that an insolvent husband voluntarily hestows his labor and skill in the business of farming carried on by his wife upon land which is her separate property, and operated with her separate property, will not, in the absence of fraud, render the products the property of the hushand and liable for his debts.

${ }^{147}$ Another difference is that in common law states where the husband's creditors attempt to seize the income from his wife's separate property, they have the burden of proving that any of the proceeds were earned as a result of the husband's skill, see Commonwealth v. Fletcler, $69 \mathrm{Ky} .171,172-73$ (1869), whereas in community property states the party claiming that the profit was produced by the capital (the separate property) would have the burden of proof, see text following note 279 infra.

148 In Glidden, the court admitted that "the property in controversy can, in no just sense, be said to be either the income, increase, or profits of the money given to Mrs. Taylor," but allowed her to share in the profits as a creditor. 16 Ohio St. at $\mathbf{5 2 1 .}$

140 See Schouler, Domestic Reiations \& 165 (5th ed. 1895).

150 See text following note 136 supra.

151 "The terms of this rule, if we may call it such, are so ample, not to say vague, that it scarcely helps us in a case that varies from these facts." Evans, stepro note 140, at 282.

152 See note 111 supra and accompanying text.

1532 AMERTCAN LAw of Property 146 (Casner ed. 1952); 1 DEFuntak 186; Note, 4 Catif. L. REv. 329-31 (1916) ; 5 R.C.L. 841-42 (1914).

164 Randolph v. Randolph, 118 Cal. App. 2d 584, 258 P.2d 547 (1953); Margolis v. Margolis, 115 Cal. App. 2d 131, 251 P.2d 396 (1952); Estate of McCarthy, 127 Cal. App. 80, 15 P.2d 223 (1932); McDuff v. McDuff, 48 Cal. App. 175, 191 Pac. 957 (1920); Lawrence Oliver, 4 T.C. 684 (1945); see Estate of Arstem, 56 Cal. 2d 239, 364 P.2d 33, 14 Cal. Rptr. 809

(1961); Tassi v. Tassi, 160 Cal. App. 2d 680, 325 P.2d 872 (1958).

15548 Cal. App. 175, 191 Pac. 957 (1920).

$158 \mathrm{Id}$. at 178,191 Pac. at 957. 
Some lawyers have even argued that Pereira limited the husband to a seven per cent return on his investment, ${ }^{157}$ but this contention has been rejected..$^{158}$

The interpretation of the Pereira case as having established a "rule" by which the income of every separate property business can be apportioned seems unfounded. The method in Pereira was used only as a means to ascertain the least amount to be credited to the husband's separate estate in the absence of other circumstances. ${ }^{159}$

The only "rule" that the court intended to state in Pereira was that some apportionment should be made, not that there should be any universally applicable proportion or method of division. ${ }^{160}$ In Estate of Gold, ${ }^{161}$ Justice Shaw, the author of the Pereira opinion, stated:

The rules regarding the character of such property were considered in Pereira $v$. Pereira .... The principle there stated is that the question what part of the subsequent profits arises from the use of this capital and what part from the personal activity, ability, and capacity of the husband is to be determined by the court from the circumstances appearing in the case, that whatever accrues froin the latter sources is community property, and that the remaining profits must be classed as separate estate. 162

The fact that Gold held the entire profit to be commumity property shows even more clearly that the court did not intend that the particular method used in Pereira should be adopted as a formula for the solution of all cases. Moreover, Gold indicates that Pereira was not meant to require an apportionment in every case. ${ }^{168}$

\section{B. Estate of Pepper}

The decision in Estate of Pepper ${ }^{164}$ initiated a he of reasoning that has led to what is generally considered a different rule ${ }^{165}$ from that of the Pereira case. The supreme court in Pepper held the entire proceeds from a nursery business to be separate property, stating:

It is, in the nature of things, impossible to apportion the crop so as to detemine what share of it has come from the soil and what share fron the exertion of inan. The product must be treated as a whole, and, if it is the growth of land separately owned it is separate property of the owner of the land.166

157 The rate of $7 \%$ was not even set by the court in Pereira; it was agreed upon by the parties and recognized on rehearing. $156 \mathrm{Cal}$. at 11, $103 \mathrm{Pac}$. at 492-93.

158 The taxpayer's argument in Todd v. McColgan, 89 Cal. App. 2d 509, 201 P.2d 414 (1949), that the $7 \%$ rate of return was a rule of property law, was rejected. See 4 WrTkrn, Sumarary of Calmornia Law 2726 (7th ed. 1960). A similar contention by this same taxpayer had been previously rejected by a federal court. Todd v. Commissioner, 153 F.2d 553, 555 (9th Cir. 1945).

159 See text accompanying note 111 supra.

100 The holding of the Pereirc case was only that whatever portion of the income is attributable to the capital invested nnust be considered separate property and whatever portion is attributable to the skill and effort of the husband must be counmunity property. See Huber v. Huber, 27 Cal. 2d 784, 167 P.2d 708 (1946).

161170 Cal. 621, 151 Pac. 12 (1915).

162 Id. at $623,151 \mathrm{Pac}$. at 13.

163 The fact that no apportionment was made in Gold, and that the decision was based on Pereira, indicates that the Gold court did not view Pereira as requiring an apportionment in all cases, let alone that it should be made in a certain way.

164158 Cal. 619, 112 Pac. 62 (1910).

165 See text following note 190 infra.

166158 Cal. at 624, 112 Pac. at 64. 
It is unfortunate that the court phrased its decision in terms of an inability to apportion. Although it has been this language that has greatly influenced the apportionment cases, ${ }^{167}$ it does not appear that the possibility of apportionment was even considered. ${ }^{168}$ The case was briefed in much the same manner as Pereira and other early cases, ${ }^{169}$ with the husband arguing that the income was all his separate property, and the wife arguing that it belonged exclusively to the community. ${ }^{170}$ The basic issue was whether the husband's nursery was a business or a farm, 171 with Mrs. Pepper conceding that if it were a farm the proceeds would be entirely separate. ${ }^{172}$ The district court of appeal had decided that the nursery was a business, ${ }^{173}$ and, relying on Professor Pomeroy's suggestion, ${ }^{174}$ held that the income from a business was not within the meaning of "rents and profits" as used by the legislature in the statute. ${ }^{275}$ In reversing, the supreme court took the view that the nursery was more like a farm than a business, ${ }^{176}$ and the income was held to be within the statutory definition of rents and profits, thus belonging to the husband's separate estate.

\section{Rationale of Pepper}

In retrospect, it may appear strange that the court in Pepper did not decide the case in the same manner as Pereira and hold that some apportionment should be made. However, there were several factors existing in 1910 that make it under-

167 See text accompanying notes 192 and 202 infra.

168 But see Verrall, Cases on Callfornia Comarunity Property 117-18 (1960). See also 4 Witrin, Summary of Caltrornia LaW 2725 (7th ed. 1960).

169 See text following note 103 supra.

170 See Appellant's Points and Authorities, pp. 23-51, Respondent's Points and Authorities, pp. 29-41, Reply Brief for Appellant, pp. 10-23, Applications for Hearing, pp. 27-34, Application for Rehearing, pp. 1-23, Appellant's Answer to Petition for Rehearing, pp. 1-6, Estate of Pepper, 158 Cal. 619, 112 Pac. 62 (1910). The wife's contention, based on Lake $v$. Bender, was that the husband's skill had been the main factor in producing the income. Reply Brief for Appellant, p. 25.

171 "The question here is whether the proceeds of the nursery conducted on the land can be considered as 'issues' or 'profits' of the land." 158 Cal. at 623, 112 Pac. at 64.

172 Reply Brief for Appellant, pp.13-15. Before the Pepper case was overruled, it was pointed out that it lacked precedent because Mrs. Pepper had conceded that the crops from a farm would all be separate property. 1 ARarstrong 480 . This was also mentioned in Estate of Neilson as one of the reasons that Pepper was overruled. 57 A.C. at 739, 22 Cal. Rptr. at 4, 371 P.2d at 748.

173 Estate of Pepper, 8 Cal. App. Dec. 720 (1909).

174 See note 87 supra. The court quoted from Professor Pomeroy's article, adopting the rationale that the mcome of a commercial enterprise was not meant to be within the term "rents and profits" as used in the California Civil Code. 8 Cal. App. Dec. at 726, 727.

175 " $[I] t$ is, it seems to us, absolutely clear that it is a business as independent of that of farming or horticulture as the business of selling fruits or vegetables or commodities of any eharacter..." 8 Cal. App. Dec. at 725.

176 The court stated that:

If the crop of grain sown and harvested by the owner of the land constitutes "issues and profits" of the land, we are unable to see why the same may not be said of young trees and plants raised on the land until they are ready for transplanting. There may be cases in which the busmess is virtually one of purchase and sale of plants, the ground being used merely to preserve the plants until sales can be effectect. In such cases it might well be said that the enterprise is so predominantly coinmercial that the profits are not to be treated as issuing from the land. But on the facts before us, the court below was not bound to [regard the case as coming within this class]. 
standable why the court did not construe Pereira to require consideration of an apportionment. ${ }^{177}$

The first of these was the notion that since the legislature had provided for rents and profits to remain separate, the owner of the separate property was entitled to devote at least enough time to his property as it would take to inake it valuable. ${ }^{178}$ This was considered "ordinary use" of the property. ${ }^{179}$ In Estate of Cudworth, ${ }^{180}$ one of the early California cases preceding Pereira, ${ }^{181}$ the money that

177 Although it is important to understand the Pepper decision in light of the prevailing attitude of the period in which it was decided, see text following note 178 infra, the decision was incorrect in several respects, apart from the concession of counsel, see note 172 supra. In the first place, the Pepper decision has no basis in its supporting authorities. The only case relied on for the proposition that the proceeds of a farm are separate property was Diefendorff v. Hopkins, 95 Cal. 343, 28 Pac. 265, aff'd per curiam, 30 Pac. 549 (1892), a case that is easily distinguished. In Diefendorff the plaintiff, claiming to be a purchaser from the husband, sued a sheriff of the City and County of San Francisco for conversion of the furniture of a boarding house. The sheriff had attached the furniture at the request of the wife's creditors. Plaintiff's case was based on the theory that the attachment was inproper because the property belonged to the liusband. The court held on two alternate theories that the furniture was the separate property of the wife. The furniture was purcliased either with money which Mr. Rix gave to his wife, or with the proceeds from the boarding loouse which was the separate property of the wife. In the first instance the furniture would constitute an outright gift to the wife and thus be her separate property; in the second, the furniture would be the wife's separate property on the grounds that the husband had inade an implied gift to Mrs. Rix by allowing her to keep and manage these earnings. At best, the case is authority only for the proposition that a husband who allows his wife to manage her own earnings will be held to have inade a gift of them to her.

Even more fault can be found with the Pepper decision on the ground that the court seemingly failed to follow the very principles expressed within its opinion. It was recognized that:

There inay be cases in which the business is virtually one of purchase and sale of plants, the ground being used inerely to preserve the plants until sale can be effected. In such cases, it might well be said that the enterprise is so predominantly commercial that the profits are not to be treated as issuing from the land.

$158 \mathrm{Cal}$. at $624,112 \mathrm{Pac}$. at $64-65$. The uncontradicted testimony elicited at the trial, however, shows that Mr. Pepper's practice was to import trees from foreign countries and eastern states in the winter, have them grafted, budded, and tended by his employees for a little over a year and place them for sale the following spring. Each year he issued price lists. For quite some time he sold the trees from a store in Petaluma, Cahifornia. See Estate of Pepper, 8 Cal. App. Dec. 720, 725 (1909).

Although the Pepper court seemed unwilling to distinguish a nursery and a farm because of the differing degrees of individual skill connected with the management of each, it was willing to distinguish the nursery from a business "virtually one of purchase and sale of plants" apparently because of the length of time the plants were held before being offered for sale. This distinction appears to be based even more on a matter of degree than the one the court refused to make.

It would seem that there was ample evidence to find that the business prospered primarily from Mr. Pepper's efforts during marriage since the nursery was run for fifteen or sixteen years before marriage at a very sinall return. Estate of Pepper, 8 Cal. App. Dec. 720, 722 (1909).

178 McKay, Conarumity Property 161 (1st ed. 1910).

179 In Diefendorff v. Hopkins, 95 Cal. 343, 28 Pac. 265, aff $d$ per curiam, 30 Pac. 549 (1892), the court held that the profits of the wife's separate property boarding house were her separate property notwithstanding the fact that some part of this income was attributable to her efforts. The court reasoned that personal labor would be involved in the production of all rents, issues, and profits in some degree but this was no reason to alter the holding that the profits were separate. See LeSourd, Community Property Status of Income from Business Involving Personal Services and Separate Capital, 22 WASH. L. Rev. \& ST. B.J. 19, 22 (1948); note 177 supra. 180133 Cal, 462, 65 Pac. 1041 (1901).

181 See also cases cited note 82 supra. 
the husband had earned from making investments with his separate capital was held not to belong to the community. ${ }^{182}$ The court reasoned that "those profits ... which have arisen naturally and without the active engagement by the husband of his capital in some business or employment" were separate property. ${ }^{183}$

The second factor that caused the Pepper court to feel that Pereira was not binding was the notion that crops grown on land are the natural product of the soil and necessarily arise from the ordinary use of the property. This notion seems to have been borrowed from the cominon law cases dealing with the attempts of a husband's creditors to reach the profits of the wife's separate property where the husband had devoted his time and skill to producing these profits. In Lake v. Bender, ${ }^{184}$ which first used these cases, ${ }^{185}$ the dissent pointed out that the principle of not allotting any part of the income to the ability of the husband was applicable

to cases where the accumulations of property were derived from conducting and carrying on the farming business, and other business of like character .... [because] the ownership of a farm necessarily carries with it the right to the products grown thereon. 186

The influence of the cases discussed by the dissent in Lake seems to have caused the Pepper court to draw a distinction between a farm and a business. The products of a farm were viewed as necessarily following from the ordinary use of land, whereas the profit from a business may or may not result from ordinary use, depending on the circumstances of the individual case.

It was a combination of these factors that was responsible for the Pepper decision. The court in Pepper undoubtedly felt that all the income from a farm issued "naturally" from the soil, notwithstanding the fact that a certain amount of labor was necessary in its production, and that all income arising naturally constituted rents and profits, thus belonging to the owner of the separate property under Civil Code sections 162 and $163 .{ }^{187}$

\section{Pepper and Pereira Reconciled}

In light of the fact that the "apportionment rule" of Pereira v. Pereira was forinulated by a resort to the same line of common law creditor cases considered in the dissent in Lake, ${ }^{188}$ Pereira may be viewed as being consistent with Pepper. Arguably, the court in Pereira decided that the income from the husband's business did not constitute rents and profits since it did not issue from the ordinary use of his property. ${ }^{189}$ Because the incone from Mr. Pereira's business in no way involved a product of the soil, the court could have decided whether such profits arose from the ordinary use of the property under the facts of the case. There not

182 The notion that the owner of property must be given its beneficial use was one of the reasons for holding that the rents and profits of the wife's separate property must be considered separate property in George v. Ransom, 15 Cal. 322 (1860). See Boyd v. Oser, 23 Cal. 2d 613,145 P.2d 312 (1944).

183133 Cal. at 468,65 Pac. at 1044.

18418 Nev. 361, 4 Pac. 711 (1884), discussed in text following note 83 supra.

185 See note 94 supra and accompanying text.

18618 Nev. at 396, 4 Pac. at 731-32; see Lake v. Bender, 18 Nev. 361, 395-400, 4 Pac. 711, 731-36 (1884) (dissenting opinion).

187 See note 1 supra.

188 Note 186 supra; see text following note 124 supra.

189 It appears that a large part of the profits may have been attributable to the gambling done by Mr. Pereira in his saloon. See Transcript on Appeal, pp. 81-85, Percira v. Pereira, 156 Cal. 1, 103 Pac. 488 (1909). 
being "ordinary use," the husband would then have been entitled only to the interest rate on the capital he had invested as if he had loaned it to the community to operate the business. Had the court desired to apportion in Pepper, they could have easily relied on Pereira, and found that the profits belonged to the community, except for the separate property's fair rental value. ${ }^{\mathbf{1 0 0}}$

\section{Van Camp v. Van Camp}

The Pepper case had its greatest impact through its use in Van Camp v. Van Camp. ${ }^{101}$ In this case, the husband was the controlling shareholder of a large incorporated business, and devoted his efforts exclusively to the management of the business. During the marriage he received a total of $\$ 141,000$ as dividends on his stock in the corporation, and a total of $\$ 90,000$ as salary which the evidence established as reasonable for the services he performed. The court found that although the salary belonged to the community, all the dividends were the husband's separate property. The court relied on Pepper for the proposition that where no apportionment of business income can be made the entire amount should be considered separate property.$^{102}$ Thus, since the court felt that it was impossible to determine what part of the dividends accrued from the skill of the husband, and what part from factors attributable only to the business, ${ }^{193}$ the whole amount was held to be separate property. ${ }^{194}$

The reliance on Pepper would seem unjustified. Pepper clearly indicated that its holding was restricted to situations involving products of the soil, and distinguished the situation where the profits take the form of business profits. ${ }^{195}$ Con-

190 This was the result reached by the court in Laughlin v. Laughlin, 49 N.M. 20, 155 P.2d 1010 (1944), where the court rejected the Pepper case and applied the Periera "rule" to a farm. 19153 Cal. App. 17, 199 Pac. 885 (1921).

192 The court stated that "the case presented is not unlike that involved in Estate of Pepper . . . wlierein it was held that the profits and earnings [were] his separate property, notwithstanding the success of the venture required industry, skill, and attention." $53 \mathrm{Cal}$. App. at 28, 199 Pac. at 889.

${ }^{193}$ After citing Pepper, the court in Van Camp said:

So, in the instant case, it is impossible to say what part of the enormous dividends paid by the Van Camp Sea Food Company should be apportioned to the skill and management thereof and what part should be apportioned to the investment of the capital and the favorable conditions under which the business was conducted.

53 Cal. App. at 28, $199 \mathrm{Pac}$. at 889.

194 The confusion that would result from an application of the Pepper reasoning to a commercial enterprise was recognized by the counsel for Mrs. Van Camp, who argued before the Supreme Court that

whatever may be determined of the corporate character of the appellant's business, the Estate of Pepper cannot be applied in this action as an authority, without confusing the law relating to the question of community property rights in the state of California, and if the principles which have heretofore been marked out by these two decisions are to be adhered to, the case of Pereira v. Pereira inust be given controlling force.

Petition for Hearing by the Supreme Court, pp. 27-28, Van Camp v. Van Camp, 53 Cal. App. 17, 199 Pac. 885 (1921).

195 It was recognized in Pepper that

there may be cases in which the busmess is virtually one of purchase and sale of plants, the ground being used merely to preserve the plants until sales can be effected [and] in such cases it might well be said that the enterprise is so predominantly commercial that the profits are not to be treated as issuing from the land. 
cerning the latter situation, Pepper acknowledged that such profits would not necessarily be considered as arising from the "ordinary use of the separately held property," indicating that they should be subjected to apportionment insofar as it was required by Pereira.

\section{The Van Camp "Method"}

As happened with Pereira, the decision in Van Camp has been extended beyond the context in which it was decided. ${ }^{196}$ In Huber v. Huber, ${ }^{197}$ the California Supreme Court first approved the "method" used in Van Camp, ${ }^{108}$ stating that a proper apportionment is to take what the evidence establishes as being the reasonable value of the spouse's services as the full amount of the community interest, with the remainder all being separate property. ${ }^{108}$ The community interest in Huber was found to be $\$ 7,200$, which the husband's accountant testified was the reasonable value of the husband's services, although the husband had taken a total of $\$ 14,400$ in salary or drawing. 200

The rule in Huber was not required by the Van Camp decision. Van Camp did not hold that the community interest was linited to the amount established by the evidence as the reasonable value of the spouse's services. It indicated only that business profits not capable of being apportioned must belong to the spouse owning the business. ${ }^{201}$ Van $\operatorname{Camp}$ did not hold that all business profits are necessarily not apportionable. ${ }^{202}$

196 As with Pereira, see text following note 150 supra, the Van Camp case has been taken as establishing a method of apportionment. In Gilmore v. Gilmore, 45 Cal.2d 142, 149-50, 287 P.2d 769, 773 (1955), the court said: "It has frequently been beld that a proper method of making such allocation is to deduct from the total carnings of the business the value of the husband's services to it. The remainder, if any, represents the earnings attributable to the separate property invested in the business." See Harold v. Harold, 43 Cal. 2d 77, 271 P.2d 489 (1954); Huber v. Huber, 27 Cal.2d 784, 167 P.2d 708 (1946); Belmont v. Belinont, 188 Cal. App. 2d 33, 10 Cal. Rptr. 227 (1961) ; Mears v. Mears, 180 Cal. App. 2d 484, 4 Cal. Rptr. 618 (1960); Tassi v. Tassi, 160 Cal. App. 2d 680, 325 P.2d 872 (1958); Logan v. Forster, 114 Cal. App. 2d 587, 250 P.2d 730 (1952); Cozzi v. Cozzi, 81 Cal. App. 2d 229, 183 P.2d 739 (1947); Gump v. Counmissioner, 124 F.2d 540 (1941).

18727 Cal. 2d 784, 167 P.2d 708 (1946).

198 Sce 1 ARMSTrONg 478.

199 Some courts have even taken the view that the Van Camp "inethod" himits the community to the actual salary that the liusband draws. In Seligman v. Seligman, 85 Cal. App. 683, 687,259 Pac. 984, 986 (1927), the court stated: "Not the profits of the business, but only the earnings of the plaintiff from his individual efforts, or what might be called his salary or wages, would be community property." See Shea v. Commissioner, 81 F.2d 937, 939 (1936) ; Horne, Community Property-A Functional Approach, 24 So. CAI. L. REv. 42, 53 (1950); Comment, 1 So. CAL. L. Rev. 161, 162-63 (1927).

The New Mexico courts rejected the Pepper decision in Laughlin v. Laughlin, 49 N.M. 20 , 155 P.2d 1010 (1944), but adopted the Van Camp "method" in Katson v. Katson, 43 N.M. 214, 89 P.2d 524 (1939), and found that the community was linited to the salary. See Coinment, 36 TEXas L. Rev. 187, 193-94 (1957).

200 Thus, the Huber case put to rest the contention that the Van Camp "method" linnited the community to the actual salary of the husband. See Tassi v. Tassi, $160 \mathrm{Cal}$. App. 2d 680, 325 P.2d 872 (1958); note 199 supra.

201 See notes 192-93 supra and accompanying text.

202 In the sense that the Van Camp case held that the salary was community but that all the dividends were separate, the case can be taken as a combimation of Pepper and Pereira. See Verrati, Cases on California Commonity Property 118 (1960); Evans, Primary Sources of Acquisition of Community Property, 10 CauTF. L. REv. 271, 282 (1922); Note, 14 CaLIF. L. REv. 402, 404 n.15 (1926). 
Whether there still exists a sound basis for using the Van Camp "method" depends on the effect of Estate of Neilson in overruling Pepper, ${ }^{203}$ since the latter case was relied on in the Van $\operatorname{Camp}$ decision. ${ }^{204}$

\section{The Problem of Increase}

In Gilmore v. Gilmore, 205 the Van Camp "method" was used to apportion the increased value or appreciation of the husband's separately owned business. ${ }^{208}$ Professor Burby suggests that it was unwise to consider the increase in a business in the same manner as its profits, ${ }^{207}$ apparently arguing that the appreciated value of separate property should belong to the community. This contention could be supported on the basis that Civil Code sections 162 and $163,{ }^{208}$ the provisions defining separate property, do not include the increased value of separate property, and that the residual definition of community property would thus apply to the increase, making it community property. ${ }^{209}$ Furthermore, since the statutes of other states include increase in their definitions of separate property, ${ }^{210}$ it could be argued that the Legislature of California, by omitting the mention of increase from their definition, intended increases to belong to the community.

These arguments, however, overlook the fact that the increase of separate property remained separate under the original Spanish-Mexican laws. ${ }^{211}$ Even states like Texas, which continue to classify the rents and profits of separate property as belonging to the community, classify the increase as separate. ${ }^{212}$ As stated by the Washington court in Guye v. Guye, ${ }^{213}$ "since by the statute the spouse owning separate property is entitled to the rents, issues and profits thereof, so such owner must be entitled to the natural increase in value, as such increase is as much the issue of such property as would be the rents derived therefrom." 214

203 See note 272 and text accompanying note 273 infra.

204 See text accompanying note 192 supra.

20545 Cal. 2d 142, 287 P.2d 769 (1955).

206 In Gilmore the wife contended that the increase in value of the busband's three incorporated auto dealerships from $\$ 182,010.46$ to $\$ 786,045.52$ should be partially allocated to the community. The court, however, applied the $\operatorname{Van}$ Camp "method" and held that the salary or drawings of the husband had been adequate compensation for his services; thus, the entire amount of increase was apportioned as his separate estate.

207 Farmity Law For Calmornia Lawyers 369 (Cont. Ed. Bar 1956).

208 CAx. CIv. Code $\$ \S 162,163$. See note 1 supra.

209 CAI. CIV. CODE $\$ 687$ : "Community property is property acquired by husband and wife, or either, during marriage, when not acquired as the separate property of either." See Dow v. Gould \& Curry Silver Mining Co., 31 Cal. 629 (1867); CaL. CIv. Code $\$ 164$. See also Estate of Gold, 170 Cal. 621, 151 Pac. 12 (1915); 2 Tiffany, Real Property § 439 (3d ed. 1939); Evans, Owmership of Community Property, 35 Harv. L. REv. 47 (1921). But see deFuntak, Cases on Comaruntty Property 58 (1947).

210 See, e.g., ARIz. REv. STaTs. ANN. \$ 25-213 (1956).

211 Scemmid, The Civil LaW of Spann and Mexrco pt. 2, at 13 (1851) (art. 47); 1 Whrte, A New Cottection of tee Laws of the Governments of Great Britann, France and Spatn 61-63 (1839); see Escriche, Diccionario Razonado DE LeGIStacion y JURISPRUdENCIA 367 (1925) ; Huie, Some Principles of Texas Community Law, in Chararatz \& Daggetr, Comparative Studies IN Conamuntry Property 115, 116-17 (1955).

212 Tex. Rev. Civ. Star. Ann. art. 4613 (1960).

21363 Wash. 340, 115 Pac. 731 (1911).

214 Id. at 348, $115 \mathrm{Pac}$. at 734. Recently the California Supreme Court recognized that "any increase in the value of the land attributable to plaintiff's [husband's] efforts was also community property." Mayhood v. LaRosa, 58 A.C. 510, 512, 374 P.2d 805, 806, 24 Cal. Rptr. 837 (1962). 
Since the increased value of a business may in part be attributed to what is in effect a reinvestment of the profits, it is difficult to distinguish rationally the profits of a business from its increase. Thus, if the skill and efforts of a spouse are at least in part responsible for the increase, the increase resulting from such efforts would seem allocable to the community in the same manner as business profits. ${ }^{215}$

\section{The Tax Formula}

Because of the divergence in approach, the results reached under the Pereira "rule" and Van Camp "method" are at opposite extremes. In any given case, if the apportionment were first to be made in accordance with the Pereira interest rate formula, and then separately computed in the manner indicated by $\operatorname{Van} \operatorname{Camp}$, part of the total income may remain unallocated to either. ${ }^{210}$

Recognizing this hiatus in the results of the Pereira "rule" and Van Camp "method," Professor Burby ${ }^{217}$ and Professor Moynihan ${ }^{218}$ have suggested that the formula apphed in tax cases be used as a compromise. 210 This "tax formula" involves first computing both the fair rate of return of the separate capital invested in the business, and the value of the services rendered. ${ }^{220}$ The ratio of the value of the services is then taken to the total of the fair rate of return and such value of services, with the ratio being multiplied times the total profits in dispute to establish the share of the community. The share of the separate estate is determined by taking the ratio of the fair rate of return to the same denominator as above, and again multiplying times the total profits. ${ }^{221}$ This tax formula is actually a means of dividing the difference between the value the courts place on the services and the rate of return given the capital. ${ }^{222}$ The fact that a difference exists

215 See Oppenheim, A Comparative Study of Community Property Systemts, 21 TEMr. L.Q. 235 (1948). See also Emery, Mutations, 4 Sw. L.J. 123, 126-27 (1950).

216 If, in a hypothetical case, the husband had $\$ 100,000$ invested in his separate property business which earned $\$ 38,000$ a year, and from which he drew a salary of $\$ 12,000$, the amount given the separate estate will vary greatly depending on which method of apportionment is used. If the Pereira method is used, the court would apply a rate of about $7 \%$ and find that $\$ 7,000$ was separate property and $\$ 31,000$ was community property. If the court were to apply the $\operatorname{Van} \operatorname{Camp}$ rule, they would probably find that his salary was the reasonable value of his services, and $\$ 12,000$ would be held to be community property with the remaining $\$ 24,000$ going to his separate estate. Thus if the husband was given $\$ 7,000$ by applying Pereira, and the community given $\$ 12,000$ under Van $\operatorname{Camp}$, there would remain $\$ 19,000$ unallocated to either.

217 Burby, Cases on Comanunity Property 91 (2d ed. 1955).

2182 american Law of Property \& 7.12, at 147-48 (Casner ed. 1952).

210 This formula was first promulgated in G.C.M. 9825 ; X-2 CuM. BuLt. 146 (1931), and first used in Clara B. Parker, 31 B.T.A. 644 (1934). See generally SURREY \& WARREN, CaseS on Federat Incone Taxation 1048-49 (1962).

220 In this sense the "tax formula" appears to be based on the idea that tivere are two different methods for making the apportionment. See Comment, 21 So. CAL. L. REv. 447, 450 n.9 (1948).

221 Thus, if the husband has $\$ 100,000$ invested in his restaurant busmess which he owned at the time of unarriage, assume that $7 \%$ would be a fair rate of return on capital, that $\$ 12,000$ would be a reasonable salary, and that the net income was $\$ 38,000$. The separate property portion would be $\$ 7,000$ (7\% of $\$ 100,000$ ) divided by $\$ 19,000$ (total of fair return and reasonable salary), multiphed by $\$ 38,000$ (the earnings for the year), or $\$ 14,000$. The community share would be $\$ 12,000$ divided by $\$ 19,000$ times $\$ 38,000$, or $\$ 24,000$.

222 If the fair return on capital plus the reasonable value of services rendered equaled the income, there would be no need to apply the ratio. In the illustration in note 221 suppra, if the net income was $\$ 19,000$ instead of $\$ 38,000$ an apphication of the ratio would result in a finding that $\$ 7,000$ was separate property and $\$ 12,000$ was community property. 
cannot logically be the basis of a solution to the problem, but rather points out that the two methods upon which the tax formula is based ${ }^{223}$ are arbitrary. ${ }^{224}$ Consequently, the tax formula itself cannot help but yield an arbitrary result. ${ }^{225}$

In addition to being arbitrary, the use of the "tax formula" in federal tax cases would also seem unjustified. The tax laws specify that property is to be classified according to the law of the state in which it is located. ${ }^{228}$ Inasmuch as the formula had never been used by a Califorma court prior to its appearance in the tax case, ${ }^{227}$ its use in the federal courts appears improper; ${ }^{228}$ these courts sliould have deterimined whether income was community or separate in accordance with the apportionment methods previously used in California civil cases. ${ }^{229}$ Moreover, the courts of the Ninth Circuit, in applying this "formula," do not take into account the basic presumption of the community property system ${ }^{230}$ that all property acquired after marriage belongs to the community. ${ }^{231}$ Rather, they presume that the Commissioner has correctly determined the tax, thereby placmg upon the taxpayer, who is normally trying to show that more commumity property exists, ${ }^{232}$ the burden of showing the character of the property. ${ }^{233}$

223 The first tax method, proposed in 1925, recognized the Pereira case as the rule in California. After the Van Cannp "method" gained acceptance, G.M.C. 9825 was proposed. See IV-2 Cusr. Bull. 125 (1925); VI-1 Cus. BuLl. 26 (1927); X-2 CuM. Bull. 146 (1931). See also LeSourd, Community Property Status of Income From Business Involving Personal Services and Separate Capital, 22 WaSH. L. Rev. \& ST. B.J. 19, 27-33 (1947); Kizer, Community Interest in Commingled Income, Derived from Personal Service and Separate CapitalAnother View, 23 Wase. L. Rev. \& ST. B.J. 8 (1948); Note, 20 So. CaI. L. Rev. 108, 110 (1946); Comment, 21 So. CaI. L. Rev. 447, 450 n.9 (1948).

224 If either the Pereira "rule" or the Van Camp "method" were accurate ways to assess the value of the separate estate, the amounts yielded by their application should equal the profits of the business. That is, if Pereira had furnished a method to determine accurately the separate property interest, and if Van Camp had set down a rule by which the community's contribution could be properly determined, their application in any given case would yield consistent results. But see note 216 supra.

225 See Kizer, supra note 223, at 10-12.

2283 Mertens, FederaI Income Taxation $\$ 19.10$ (1957).

227 Although the tax formula has been used in a California tax case, Todd v. McColgan, 89 Cal. App. 2d 509, 201 P.2d 414 (1949), it had been used many times by the federal courts before it had been adopted in California. E.g., Todd v. Commissioner, 153 F.2d 553 (9th Cir. 1945).

228 It has been suggested that the application of the "tax formula" violates the policy of Erie v. Tounkins, 304 U.S. 64 (1938). See Kizer, Community Interest in Commingled Income, Derived from Personal Service and Separate Capital-Another View, 23 WASH. I. REv. \& ST. B.J. 8, 15-16 (1948). It would not seem, lowever, that the Erie doctrine is applicable. See generally HART \& WECHSIER, THE FEDERAI CoURTS ANd tHe FederaI SysteMr 633-36 (1953); Louiseli \& Hazard, Cases on Pleading and Procedure 1271-76 (1962).

220 This apparently was realized in the first bulletin covering the income from a separate property business. See IV-2 CUM. BuLL. 125 (1925), Lawrence Oliver, 4 T.C. 684 (1945). Liahility under the federal estate tax is determined in accordance with local law. See LowndEs \& Kralger, Federac Estate and GIFt TaXes 250 (2d ed. 1962).

230 The presumption is recognized by the Fifth Circuit in tax cases. See McFadden v. Commissioner, 148 F.2d 570 (5th Cir. 1945); Howard v. United States, 125 F.2d 986 (5th Cir. 1942). The presumptions are also followed in determining liability for the federal estate tax. See J. G. Sweeney, 15 B.T.A. 1287, 1292 (1929) ; Lowndes \& KraMer, FEderaI Estate aNd GIFT TAXES 240-42 (1st ed. 1956).

231 See, e.g., Shea v. Commissioner, 81 F.2d 937 (9th Cir. 1936).

232 See LeSourd, Community Property Status of Income from Business Involving Personal Services and Separate Capital, 22 WASH. L. REv. \& ST. B.J. 19, 30-31 (1947). See also Kizer, Community Interest in Conmingled Income, Derived from Personal Service and Separate Capital-Another View, 23 WASH. I. REv. \& ST. B.J. 8, 10-11 (1948).

233 See Kizer, supra note 232, at 14-16. 


\section{E. Each Case Decided on its Facts}

The proposed use of the tax formula could be supported by language in several cases that the apportionment question is a factual one to be decided in each case by the trier of fact in any manner deemed equitable. ${ }^{234}$ Treating the apportionment of income solely as a question of fact seems to be regarded by deFuniak as the only solution to the problem of apportionment. ${ }^{235}$ Indeed, the language used in Estate of Gold ${ }^{236}$ could be taken to indicate that the "rule" intended by Pereira was only that each case must be decided in light of all the circumstances. ${ }^{237}$ Nevertheless, the construction given to Pereira by the later cases, including Estate of Neilson, ${ }^{238}$ suggests that the California Supreme Court would not presently support an unrestrained rule of apportionment. 239

Several difficulties confront deFuniak's suggestion to allow the trier of fact to make the apportionment as a purely factual matter. With no guides for handling the problem, none of the confusion in selecting from the various rules would be cleared up, and the inconsistent Pereira and Van $\operatorname{Camp}$ approaches would continue to be applied at random. Furthermore, deFuniak's approach would give practically unlimited discretion to the trial judge in deciding the character of the property. Admittedly, discretion in a trial court is desirable in many instances, but in apportionment cases the trial judge may be prone to view the fault of the parties in determining which property belongs to the community. In the past, the fault of the parties seems to have had a great deal of effect on the results reached in a given case. It is possible, for example, that the favorable apportionment given the wife in Pereira v. Pereira was made because of the extremely cruel conduct of the husband; ${ }^{240}$ the failure in Estate of Pepper to find any community property for the wife to share could be explained by the fact that the wife had destroyed all the records kept by Mr. Pepper and offered no explanation for her actions. ${ }^{241}$ Similarly, it has been suggested that the apportionment made in $\operatorname{Van} \operatorname{Camp} v$. Van Camp

234 The tax method was used by the California courts in Todd v. McColgan, $89 \mathrm{Cal}$. App. 2d 509, 201 P.2d 414 (1949), to determine the state income tax liability. The court, however, used language from federal cases to the effect that each case should be decided on its facts by any method the court chooses to apply. While the tax method has never been used in a California civil case, the courts lave cited this language from Todd, and thus this notion has entered the Califormia law. See, e.g., Logan v. Forster, 114 Cal. App. 2d 587, 250 P.2d 730 (1952).

235 See 1 DEFunIaK \& 71, at 185; DEFunIaK, Community Property, 5 SURvey of CaIIFORNIA LAW 154 (1952-1953). See also 3 Mertens, FederaI Inconse TAXation $\$ 19.38$ n.50 (1957).

236 170 Cal. 621, 151 Pac. 12 (1915).

237 This is well illustrated by Justice Shaw's statement in Gold:

The principle there stated [in Pereira] is that the question what part of the subsequent profits arises from the use of this capital, and what part from the personal activity, ability, and capacity of the husband, is to be determined by the court from the circumstances appearing in the case ....

170 Cal. at 623,151 Pac. at 13.

23857 Cal. 2d 733, 740, 22 Cal. Rptr. 1, 4-5 (1962).

239 This is indieated by the construction given Pereira in McDuff v. McDuff. See text accompanying note 156 supra. The language used in Neilson suggests a similar conclusion, where Pereira is taken as the usual rule, and explicit situations calling for departures are listed. See text following note 255 infra.

240 In Pereira, the cruelty of the lusband was of an extreme nature. Findings of Fact, Transcript on Appeal, pp. 46-50, Pereira v. Pereira, 156 Cal. 1, 103 Pac. 488 (1909); see Thomas, Apportionment in Comarunity Property States 38 (1927).

241 Application That Cause be Heard and Determined by Supreme Court After Decision by the District Court of Appeal, p. 6, Estate of Pepper, 158 Cal. 619, 112 Pac. 62 (1910). 
was influenced by the court's attitude toward the wife, whom it viewed as a gold digger. ${ }^{242}$ It thus appears that the courts are susceptible to confusing their discretion in dividing the community property ${ }^{243}$ with the decision of what property is community property. ${ }^{244}$

\section{III}

\section{APPORTIONMENT AFTER Neilson}

Although neither Van Camp v. Van Camp nor Pereira v. Pereira were intended to promulgate methods of apportionment, ${ }^{245}$ the subsequent cases proceeded along diverging lines of approach based on these two decisions. ${ }^{246}$ While there was authority that an apportionment could be made in either manner ${ }_{247}^{24}$ most commentators considered the Van Camp and Pereira methods to be inconsistent. ${ }^{248}$ In any event, it was impossible to predict which approach would be used by the courts in any given situation. ${ }^{240}$

In Estate of Neilson, ${ }^{250}$ the wife, having been disinherited by her husband, exercised her election to take half of the community property against the will. ${ }^{251}$ The trial court refused to give an instruction proposed by the heirs of the husband's estate to the effect that the income from the husband's farm was all his separate property even though the husband devoted his efforts to running the farm during marriage. The trial court stated "that the rule of Estate of Pepper has been 'practically wrecked' by subsequent cases."252 In affirming, the Supreme Court of California expressly overruled Pepper, stating that an apportionment must be made whenever one of the spouses has earned money by combining his skill with the use of a separate asset, regardless of whether the revenue has been earned through a business, farm, ${ }^{253}$ or constant reinvestment ${ }^{254}$ of separate capital.

2421 ARASTRONG 478.

243 In certain divorce situations the trier of fact must award more than one-half of the commumity property to the imnocent party, but has discretion as to what portion over one-half should be awarded. 1 Arasstrong 791-96.

244 While the discretion of the judge to view the fault of the parties in deciding how the community property should be divided is desirable, this type of discretion should have no bearing on the issue of whether property is community or separate.

245 See text following notes 150 and 196 supra.

246 Compare cases cited note 196 supra with cases cited note 154 supra.

247 In Tassi v. Tassi, 160 Cal. App. 2d 680, 690, 325 P.2d 872, 878 (1958), the court said, "Two approaches have ordinarily been made to the allocation of earnings in such cases," citing Pereira for one rule and $H u b e r v$. Huber for another.

248 Comment, 21 So. CaI. L. Rev. 447, 450 n.9 (1948); see Logan v. Forster, 114 Cal. App.2d 587, 250 P.2d 730 (1952); Shea v. Commissioner, 81 F.2d 937, 938-39 (1936); 4 Witkin, Sumarary of CarIrornia Law Community Property \$§17-18 (7th ed. 1960); cf. Comment, 1 So. CaI. L. Rev. 161, 163 (1927).

249 The disparity in result between an apphication of the Pereira "rule" and the Van Camp "method," coupled with the impossibility of foreseeing which will be applied, perhaps has some merit in that parties are more likely to settle their dispute out of court.

25057 Cal. 2d 733, 22 Cal. Rptr. 1 (1962).

251 See Estate of King, 19 Cal.2d 354, 121 P.2d 716 (1942) ; cf. CaI. Prob. Code § 201.7. The nature of the wife's claim is not the same as the husband's claim. See CarIForNIA EsTate ADAINISTRATroN §§ 26.46, 26.48 (Cont. Ed. Bar 1959).

$25257 \mathrm{Cal} .2 \mathrm{~d}$ at $738,22 \mathrm{Cal}$. Rptr. at 4.

253 The court stated that "there is no reason wby a grain farmer or nursery operator who conducts his enterprise on separate property should be exempted from the normal apportionment rule and not reqnired to account to the community for a portion of the profits." Id. at 741, 22 Cal. Rptr. at 5.

254 Justice Traynor stated that, "An apportionment of profits is required not only when 
Having decided that an apportionment must be made, Justice Traynor stated that the usual method of making such an apportionment is in accordance with the rule of Pereira. ${ }^{255}$ A departure from Pereira, according to Justice Traynor, should be made only when the husband can show that his capital is entitled to a greater return. ${ }^{256}$ This showing can be established by proof that there were unusually large profits and increases in other businesses of the same type; ${ }^{257}$ that the spouse did not take an active part in the control of the business; ${ }^{258}$ that there has been a general increase in population and economic growth in the community; ${ }^{250}$ or that the business requires a large sum of capital..$^{200}$

the husband conducts a commercial enterprise but also when he invests separate funds in real estate or securities." Id. at 740,22 Cal. Rptr. at 5. Although the language used might indicate that this was settled law, there had been much confusion whether investing in securities and real estate was a business and came within the rules relating to apportionment. 1 CALIForNIA FaMeII Lawyer $\$ 4.23$ (Cont. Ed. Bar 1961); LeSourd, Community Property Stalus of Income From Business Involving Personal Services and Separate Capital, 22 WASH. L. REv. \& Sr. B.J. 19, 24-25 (1947).

255 The language that Pereira is the "usual method" was first used in Randolph v. Randolph, 118 Cal. App. 2d 584, 258 P.2d 547 (1953), although similar language was used earlicr in Stice v. Stice, 81 Cal. App. 2d 792, 185 P.2d 402 (1947). While no citation was given for the language in Randolph, it is interesting to note that the language appears to have originated in 3 Cax. JuR. 534 (Ten Yr. Supp. 1936). See Brief for Respondent, pp. 6-7, Randolph v. Randolph, 118 Cal. App. 2d 584, 258 P.2d 547 (1953).

256 In Neilson, the court quoted from Randolph to the effect that: "Only when the profits and accruals actually attributable to the separate property are proved to differ from [the usual interest rate for a well secured investment] . . . is there reason to depart from this system.'" 57 Cal. 2d at 740, 22 Cal. Rptr. at 5.

257 Ibid., citing Gilmore v. Gilmore, 45 Cal. 2d 142, 287 P.2d 769 (1955) ; Harrold v. Harrold, 43 Cal.2d 77, 271 P.2d 489 (1954); Tassi v. Tassi, 160 Cal. App. 2d 680, 325 P.2d 872 (1958).

25857 Cal. 2d at 740, 22 Cal. Rptr. at 5, citing Gilmore v. Gilmore, 45 Cal. 2d 142, 287 P.2d 769 (1955); Logan v. Forster, 114 Cal. App. 2d 587, 250 P.2d 730 (1952); Cozzi v. Cozzi, 81 Cal. App. 2d 229, 183 P.2d 739 (1947). See also Estate of Graniss, 142 Cal. 1, 75 Pac. 324 (1904); Estate of Cudworth, 133 Cal. 462, 65 Pac. 1041 (1901); Estate of Higgins, 65 Cal. 407, 4 Pac. 389 (1884); Kenney v. Kenney, 128 Cal. App. 2d 128, 274 P.2d 951 (1954); Estate of Barnes, 128 Cal. App. 489, 17 P.2d 1046 (1932); Gump v. Commissioner, 124 F.2d 540 (9th Cir. 1941).

25057 Cal. 2d at 740, 22 Cal. Rptr. at 5, citing Gilmore v. Gilmore, 45 Cal. 2d 142, 287 P.2d 769 (1955), Logan v. Forster, 114 Cal. App. 2d 587, 250 P.2d 730 (1952). See also Berry v. Berry, 117 Cal. App. 2d 624, 256 P.2d 646 (1953); Gump v. Commissioner, 124 F.2d 540 (9th Cir. 1941).

$26057 \mathrm{Cal} .2 \mathrm{~d}$ at 740, $22 \mathrm{Cal}$. Rptr. at 5, citing Huber v. Huber, $27 \mathrm{Cal} .2 \mathrm{~d} 784,167$ P.2d 708 (1946). Other cases have shown that if the inactive spouse can prove that the capital was not an important factor, and that the profits are due almost entirely to the skill and ability of the active spouse, the entire profit would be community. Austin v. Austin, 190 Cal. App. 2d 45, 11 Cal. Rptr. 593 (1961) ; Estate of Fellows, 106 Cal. App. 681, 289 Pac. 887 (1930); cf. Estate of Gold, 170 Cal. 621, 151 Pac. 12 (1915).

Under the Neilson decision, there can be an allocation of the entire proceeds and increment only when they are attributable solely to the natural enhancement of the property, 57 Cal. $2 \mathrm{~d}$ at 740, 22 Cal. Rptr. at 5, citing Estate of Cudworth, 133 Cal. 462, 65 Pac. 1041 (1901); McDuff v. McDuff, 48 Cal. App. 175, 191 Pac. 957 (1920), or when the husband expended only minimal effort and the wife introduced no evidence attributing a value to his services, 57 Cal. 2d at 740, 22 Cal. Rptr. at 5, citing Cozzi v. Cozzi, 81 Cal. App. 2d 229, 183 P.2d 739 (1947) ; Estate of Barnes, 128 Cal. App. 489, 17 P.2d 1046 (1932). See discussion in text following note 282 infra. See also Estate of Heltcel, 200 Cal. App. 2d 398, 19 Cal. Rptr. 352 (1962). In New Mexico there is no apportionment made if the increase is due to the natural enhancement of the property. Crark, Comaruntry of Property and the Fammy in New Mexico 19 (1956). 
From the unlesitating manner in which the Pereira method was applied, it would appear that little confusion had ever existed. However, Justice Traynor's straightforward application of the Pereira rule as the usual method is surprising in view of lis prior opinion in Gilmore v. Gilmore. ${ }^{261}$ In the latter opinion, he stated that the Pereira rule was applicable "only in the absence of other circumstances"; ${ }^{202}$ the trial court's use of the $\operatorname{Van} \operatorname{Camp}$ method $^{203}$ was lield sustained by the evidence. Although the language of Gilmore taken literally miglit appear consistent with Neilson, ${ }^{204}$ the differing emphasis in the two cases would seem to suggest that a change has occurred in the supreme court's attitude towards apportionment. The language in Gilmore indicated that the Van Camp inethod was preferred, and that Pereira was more of an exception. In fact, the Gilmore decision prompted Professor Marsh to write that "the Supreme Court in Gilmore in effect overruled Pereira...."205 Thus, although Neilson has dispelled any thought that Pereira is overruled, the extent to which it is now to be applied is still uncertain.

The decision in Neilson purports only to reiterate what the proper method of apportionment is; it does this by citing previous apportionment cases with approval. Justice Traynor's opmion, however, is the first decision by any California court to consider all the relevant cases in stating the manner for making an apportionment, ${ }^{266}$ and he lias in effect woven the old cases into a new pattern. In the past, the courts generally have either relied on the Van Camp line of cases without considering the Pereira method, ${ }^{267}$ or conversely liave used Pereira without mention of Van Camp. ${ }^{268}$ Neilson makes no comment on the apparent inconsistency of the two approaches, but rather makes Pereira the starting point of an apportionment problem, with the criteria used in cases applying Van Camp serving in some manner to modify the result reached with Pereira.

Justice Traynor lists several criteria for determining when Pereira may be departed from, ${ }^{209}$ but he fails to state whiat is to be done once the departure is made. Since the cases cited as illustrative of the criteria for departure all use the Van Camp approacli ${ }^{270}$ it is possible that Justice Traynor intended a complete departure from Pereira to the Van Camp method once the relevant criteria are established. ${ }^{271}$ However, a departure from Pereira need not entail a complete switch to Van Camp. In keeping with the use of Pereira as the usual method under

26145 Cal. 2d 142, 287 P.2d 769 (1955).

202 Id. at 150,287 P.2d at 774.

263 See text following note 196 supra.

204 Application of Pereira only "in the absence of other circumstances," as suggested by Gilmore, is not necessarily inconsistent with the use of Pereira as the "usual method" under Neilson, particularly in view of the "other circumstances" mentioned by Neilson as reasons for departing from Pereirc. See text following note 256 supra. But whether a departure from Pereira under the Neilson framework calls for application of Van Camp is unclear. See text following note 269 infra. If Van Camp may still be applied, then Gilmore and Neilson are at least to some extent consistent. See note 272 infra.

2051 Catifornia Fadrity Lawyer $\$ 4.23$, at 115 (Cont. Ed. Bar 1961).

200 See cases cited in notes 256-60 supra. In Gilmore v. Gilmore, 45 Cal. 2d 142, 150, 287 P.2d 769, 774 (1955), Justice Traynor attempted to reconcile the Pereira and Van Camp rules, but he did not list the factors that called for a departure from Pereira.

207 See, e.g., Belmont v. Belmont, 188 Cal. App. 2d 33, 10 Cal. Rptr. 227 (1961).

208 See, e.g., Estate of Arstem, 56 Cal. 2d 239, 14 Cal. Rptr. 809 (1961).

200 See text at notes $257-60$ supra.

270 See notes $257-60$ supra.

271 This would make the Gilmore and Neilson decisions more readily reconcilable. See note 264 satpra. 
the renewed emphasis of $N$ eilson, the various factors, if established, could be used only to modify the rate of return on the separate investment. The Pereira approach of first establishing a reasonable return for the separate estate could be basically adhered to, with the relevant factors then bearing only on what is the return. ${ }^{272}$

Since it still is not clear when the Pereira or Van Camp methods are to be apphed, even though Pereira is now preferred as the "usual method,"273 it is important to analyze in what respects these methods differ. This will assist in deciding if and when it would be desirable to switch from Pereira to Van Camp under the framework set forth in Neilson. In theory, the two methods can be reconciled as differing only in approach, with the Van Camp method inquiring what the probable contribution of the spouse's efforts were in earning the income, while Pereira inquires what was the probable contribution of the capital. ${ }^{274}$ If both approaches achieved their intended goals, it would not be particularly important which method was used.

In practice, however, an application of $\operatorname{Van} \operatorname{Camp}$ can yield a result different

272 Since Neilson stated that "the long hine of cases starting with Pereira dispels any notion that such inpossibility [of apportionment] justifies a finding that none of the proceeds belongs to the commumity," 57 Cal.2d at 741, 22 Cal. Rptr. at 5, a question remains whether the Van Camp "method" can still properly be used in California. As noted heretofore, see text following note 191 supra, the decision in Van Camp was based on the language in the Pepper case that where profits cannot be apportioned they must be considered as rents and profits of separate property, and, as such, allocated to the separate estate. Now that Pepper has been overruled, it would appear that the foundation of the $\operatorname{Van} \operatorname{Camp}$ decision has been destroyed and that the holding of that case is itself no longer valid. However, the Van Camp case has been misconstrued and has been understood to stand for an apportionment inethod not actually put forth by the opinion. See text following note 196 supra. Inasmuch as this method has become an accepted part of California jurisprudence through its use in cases not relying on the Van Camp decision, see, e.g., Huber v. Huber, 27 Cal. 2d 784, 167 P.2d 708 (1946), it is doubtful that Neilson has rejected the Van Camp "method," although the case itself may no longer be good law. By failing to explain how an apportionment should be inade when a departure from Pereira is indicated, see text following note 269 sttpra, Neilson has left room for dispute concerning the propriety of using Van Camp.

273 Neilson reversed the decision of the lower court on the ground that the jury had misinterpreted the trial court's instruction relating to the transmutation of the busband's sep. arate property into community property. $57 \mathrm{Cal} .2 \mathrm{~d}$ at 743, $22 \mathrm{Cal}$. Rptr. at 7 . Although the Supreme Court considered the evidence in order to aid the trial court on remand on the issue of transmutation, id. at 743-46, 22 Cal. Rptr. at 7-9, it failed to make any comment on the evidence with regard to the issue of apportionment. The husband's heirs had argued that the income during the marriage was attributable primarily to the natural enhancement of the husband's separately owned property, apart from any reliance on Pepper. Appellant's Reply Brief, p.11, Estate of Neilson, $181 \mathrm{Cal}$. App. 2d 769, 4 Cal. Rptr. 542 (1961). They further urged the Gilmore case as precluding the application of Pereira. Appellant's Reply Brief, pp.11-14. The wife on the other hand urged the Pereira rule, arguing that gifts by the husband more than accounted for the value of the separate estate as determined under Pereira, relying on White v. White, 26 Cal. App. 2d 524, 79 P.2d 759 (1933), for the proposition that any gifts made by the husband would be presumed to have been made out of his own separate property. Respondent's Brief, p. 23, Respondent's Answer to Appellants' Petition for a Hearing by the Supreme Court, pp. 20-23. Neilson thus clearly presented the clash between Van Camp and Pereira, and it is unfortunate that the situation was not used to elaborate further on the application of these diverse approaches.

274 The holding in Pereirc was restricted to what the minimun amount of separate property would be. See note 160 supra and accompanying text. This was apparently realized in Estate of McCarthy, 127 Cal. App. 80, 15 P.2d 223 (1932), where the court stated:

In determining what portion of such profits is community property, while it must be presumed in the absence of evidence that some thereof were due to the capital 
from one reached upon application of Pereira. ${ }^{275}$ As the Gilmore ${ }^{276}$ case shows, courts applying the Van Camp method are prone to accept the testimony of the husband or his accountant that his salary accurately reflects his value to the business. Similarly, the $H u b e r^{277}$ court limited the community to the amount testified to by the husband's accountant as being reasonable compensation for his services, even though the luusband had drawn twice that amount from the busmess. ${ }^{278}$ Perhaps the courts give controlling weight to this testimony of the husband because the Van Camp approach does not produce other evidence for the courts to consider. As a practical matter, an application of $\operatorname{Van} C a m p$ cannot give effect to the basic presumption that all property acquired during marriage is community ${ }^{279}$ and still produce enough evidence for the trier of fact to make an accurate determination. Tlie basic presumption places the risk of nonpersuasion as well as the burden of going forward upon the party who is asserting that the property is separate. ${ }^{280}$

invested, and would equal at least the usual interest on a long term investment well secured, yet if the husband claims that his capital was entitled to a greater return than legal interest the burden of showing the fact rests upon him.

Id. at 86,15 P.2d at 225 . However, Pereira was soon interpreted as holding that the entire separate property interest was to be determined by affixing the rate of return indieated above. See text following note 149 supra; Randolph v. Randolph, 118 Cal. App. 2d 584, 587, 258 P.2d 547,549 (1953), where the court states:

The usual method of determining the value of a husband's mterest in a business in which be works and in which he also uses his separate property is to allow the husband the amount so invested by him with interest at the usual rate for well secured investments; profits or accruals in excess of that amount are then considered community property as attributable to the husband's personal labor, ability, energy and character [citing Pereira].

Pereira v. Pereira unay thus be viewed in more than one aspect. Aside from the actual holding of the case, the courts have come to take Pereira as a method for solving apportionment problems. Furthermore, the method itself may be taken as setting forth an approach that requires the initial allocation to be made to the separate estate, and a subsequent allocation of any remainder to the community. See text following note 292 infra.

As regards the use of Pereira as a method, in conjunction with the Van Canip approach, see Margolis v. Margolis, 115 Cal. App. 2d 131, 251 P.2d 396 (1952), where the court awarded Mr. Margohis a $6 \%$ return on his capital as the sole separate property investment, stating that "the court did not arhitrarily or unfairly determine that his assets held in 1950, less that part attributable to his managerial skills, were then his separate estate." Id. at 137, 251 P.2d at 400.

275 See note 216 supra, for a typical example.

276 Gilmore v. Gilmore, 45 Cal. 2d 142, 287 P.2d 769 (1955).

277 Huber v. Huber, 27 Cal. 2d 784, 167 P.2d 708 (1946).

278 See text accompanying note 197 supra.

270 Car. Crv. CODE $\$ 687$. Although the statute was not enacted until 1872, this presumption was recognized early in Cabifornia. Smith v. Smith, 12 Cal. 216, 224 (1859); Meyer v. Kinzer, 12 Cal. 247, 252-54 (1859) ; Levitr, The Law of Community Property 59 (1950). The presumption was recognized earlier by implication in Alverson v. Jones, 10 Cal. 9 (1858); Bessie v. Earle, 4 Cal. 200 (1854); 1 Ararstrong 441 ; see Conary, The Historic Spanish Origin of Caiffornia's Comimunity Property Law 14 (1957).

280 Because the courts have used the term to describe two separate and distinct burdens, the words "burden of proof" have been eliminated by the Model Code of Evidence, and two new terms, "burden of persuasion of a fact" and "burden of producing evidence of a fact," have been adopted. MODEI CODE of EvIDENCE rule 1(2)-(3), comment at 73-74 (1942); see 9 Wigmore, Evidence $\S \S 2485,2487$ (3d ed. 1940). See also Morgan, Some Observations Concerning Presumptions, 44 HaRv. L. Rev. 906, 927-28 (1931). In the text herein the term "burden of going forward" is used to describe "burden of producing evidence of a fact" and the term "risk of nonpersuasion," see 9 WIGMORE, EvIDENCE $\$ 2485$ (3d ed. 1940), is used to describe the "burden of persuasion of a fact." 
If, however, this risk is to be placed on the husband under the Van Camp method, he could meet his burden of going forward by having his accountant testify as to the reasonable value of his services. Because Van Camp defines the issue in terms of valuing the husband's skill, this would be direct evidence on the issue, and may strongly influence a decision in the husband's favor, particularly in the absence of any further evidence. The husband's evidence should not, however, negate the basic presumption favoring the community, and the wife should be able to win without introducing any evidence. Nevertheless, the courts usually give controlling weight to the husband's evidence under the Van Camp method.281 The wife is, in effect, forced either to come forth with additional evidence tending to limit the return on the separate investment, or to gamble that the husband's evidence will not be conclusive.

The foregoing analysis may not be consistent with a part of the Neilson opinion wherein Justice Traynor states:

The proceeds and increment in value are apportioned entirely to the husband's estate only when they are attributable solely to the natural enhancement of the property ... or when the husband expended only minimal effort and the wife introduced no evidence attributing $a$ value to his services.282

But, the last twelve words of this passage are inconsistent with another part of the opinion in which it is said to be incumbent upon the owner of a business to prove that it is making a higher rate of return than the usual interest rate. ${ }^{283}$ Justice Traynor thus seems to acknowledge that some burden rests on the party who is asserting that the property is separate. ${ }^{284}$ While the husband may introduce evidence that a higher return is justified, this should not place a burden of persuasion on the wife to establish what portion of the profits are community property. The quoted language should be taken to mean only that the establishment of certain facts by the husband shifts the burden of going forward to the wife, and not the burden of persuasion. However, Cozzi v. Cozzi $i^{285}$ and Estate of Barnes, ${ }^{280}$ the two cases $N$ eilson relies on for this language, held that the wife must bear the risk of proving that some part of the profits were community. Neither Cozzi nor Barnes considered the presumption that all property acquired after marriage is community.

Because Pereira as the usual method requires the husband to prove any greater than normal value of his capital, the basic presumption of community property can be more readily adhered to. Evidence as to the value of the husband's services does not now go directly to the issue, and is less likely to be taken by the courts as conclusive. Thus, under Pereira, the husband is induced to come forth with more evidence, and is required to prove with greater particularity the value of his

281 See text following note 276 supra.

28257 Cal. 2d at 740, 22 Cal. Rptr. at 5. (Emphasis added.)

283 In Neilson, Justice Traynor stated that, "Departures from the Pereira formula have been made when the husband introduced evidence that 'a larger return on his capital had in fact been realized." " 57 Cal. $2 \mathrm{~d}$ at 740, 22 Cal. Rptr. at 5, citing Gilmore v. Gilmore, 45 Cal.2d $142,150,287$ P.2d 769, 774 (1955).

284 With Pereira being the usual method under Neilson, the husband, notwithstanding any evidentiary burden, may get some return on his separate investment even without introducing any evidence. But see text following note 292 infra. The burden possibly placed on the husband by Neilson relates only to his receiving a larger than usual return. See note 283 stipra.

28581 Cal. App. 2d 229, 183 P.2d 739 (1947).

$28 \mathrm{~B} 128$ Cal. App. 489, 17 P.2d 1046 (1932). 
separate estate in the production of the income. ${ }^{287}$

Difficulties may arise from the use of Pereira as the usual method unless previous limitations in its application are eliminated. Some cases have used the original language of Pereira and determined that the "usual interest on a long investment well secured" sliould be allocated to the separate property. ${ }^{288}$ Other decisions have determined that the Pereira method consists of allowing the legal interest rate. ${ }^{289}$ Neither of these two rates is very closely related to practical reality. The use of the rate on a well secured investment does not give consideration to the risk factor, which is of primary importance in determining the return on any investment. ${ }^{200}$ The separate capital in the husband's business is an equity investment rather than a loan, and is unsecured rather than "well secured."291 Similarly, the use of the legal interest rate ignores the possibility that the husband may have made a better or worse than average investment. It would seem that the amount to be attributed to the separate investment should be the usual rate of return on investments in similar enterprises operating in generally the same environment.

The relatively narrow and limited interpretation given to the Pereira approach in the past has worked injustice in two respects. Where a large sum of money is in dispute, allocation to the separate estate of a conservative rate of return does not adequately reward the investment, and the community gets more than a reasonable value for the spouse's efforts. On the other liand, where the business has been only a marginally successful or losing investment, the community suffers. These problems arise because the difference between Pereira and Van Camp has been taken as bearing upon which interest, the separate estate or the community, is to be credited or paid first. It was thouglit that the $\operatorname{Van} \operatorname{Camp}$ method called for subtracting the community interest first, with the remainder being considered separate property. ${ }^{292}$ Pereira was taken to require the separate estate to be credited first, witl anything remaining being allocated to the community. ${ }^{293}$ Under this

287 The Neilson decision does not, however, make clear how such evidence is to be used. See note 273 and text following note 269 supra. The evidence produced may require a switch to the Van Camp approach, see text at note 270 supra, or may be used only to modify the return to be given the separate investment while staying within the framework of Pereira, see text following notes 271 supra and 301 infra.

Further reasons may also suggest preference for the Pereira approach. An apportionment in terms of the fair rate of return on the separate capital may be more suitable for an accurate determination, since there are usually businesses similarly situated that can be used as guides in estahlishing the share attributahle to the capital. Also, evidence is available as to the earning value of various types of invested funds. See DUN \& BRADSTREET, INC., How DoEs Your BusIness Comprare Witr Others in Your LINe? (1960); 13 MatL-ME-Monday Barometer of SAIALL BUSINESS, YEARBOOK (1961). In comparison, figures on which to value the husband's efforts would not seem as accurate. The skill and abilities required to operate a business are numerous and varied, and aside from the case of ministerial positions different people can rarely be said to possess the same degree of capability. See note 323 infra. Even the value of the husband's ability as measured by job offers or previous employment may have hittle bearing on his value to the particular business in question. See note 324 infira.

288 See, e.g., Stice v. Stice, 81 Cal. App. 2d 792, 185 P.2d 402 (1947).

280 See, e.g., Tassi v. Tassi, 160 Cal. App. 2d 680, 325 P.2d 872 (1958).

299 See 1 Catrfornia Family Lawyer § 4.23, at 115 (Cont. Ed. Bar 1961).

201 Ibid.

292 See 4 Witkn, Sunarary of California Law Community Property § 19, at 2726-27

(7th ed. 1960).

203 See Evans, Primary Sources of Acquisition of Community Property, 10 CarrF. L. Rev. 271,282 (1922). 
latter interpretation of Pereira, in a marginally successful or losing business where the entire profit is about the same or less than the arbitrary return given on the investment, there would be little or nothing left for the community after payment to the separate estate. ${ }^{294}$ The Pereira case clearly did not intend such a result. This was shown in Estate of Gold, ${ }^{295}$ where Justice Shaw, who also wrote the Pereira opinion, interpreted it as holding that "whatever accrues from the personal activity, abihty, and capacity of the husband is community property and the remaining profits must be classed as separate estate."208 Fundamental accounting and good business practice would seem to uphold this language in Gold, since labor expenses must be first satisfied before any profit or return on capital can be declared. ${ }^{297}$ If the husband had chosen not to run the business himself, he would have had to pay wages to a manager before any profit was realized on his separate investment. ${ }^{298}$ Therefore, in view of Gold, the Pereira method should not be used to give an arbitrary return to the separate estate to the detriment of the community interest. ${ }^{299}$ Similarly, there appears to be no reason why it should act arbitrarily to the detriment of the separate investment when a large rather than small sum is in dispute.

In Neilson, Justice Traynor seemed to recognize the inadequacy of using either the legal interest rate or the rate on a long-term investment, as he stated the Pereira rule as calling for a "fair rate of return." 300 If this language is taken literally, rather than being understood as calling for one of the rates used in past cases, a proper result could be reached. Evidence relating to the value of the husband's services, the returns on similar business investments, as well as the several factors set forth in Neilson, could be used to determine what rate of return would be the "fair" value of the capital. If this were done, and the husband was actually given

A logical basis for the framework would seem to be the basic presumption that

294 See McDuff v. McDuff, 48 Cal. App. 175, 191 Pac. 957 (1920). See also Note, 14 CArIr. L. REv. 402, 404 nn.16-17 (1926); Evans, Primary Sources of Acqutisition of Commmenity Property, 10 CarIF. L. REv. 271, 282 (1922).

Courts using the Van Camp method often conclude that no community property exists by holding that where the expenses are greater than the income, the community has earned nothing. See, e.g., Huber v. Huber, 27 Cal. 2d 784, 167 P.2d 708 (1946). The rationale for this holding is a presumption that all expenses were paid out of community property. Kenney v. Kenney, 128 Cal. App. 2d 128, 274 P.2d 951 (1954); see Estate of Ades, 81 Cal. App.2d 334, 184 P.2d 1 (1947). This presumption has arisen out of the statement in Estate of Cudworth, $133 \mathrm{Cal} .462$, 65 Pac. 1041 (1901), that there is no presumption that the husband paid the expenses out of his own separate property. It would seem that saying there is no presumption debts are paid out of separate property is not support for a finding that there is a presumption that such debts were paid from community funds. See Respondant's Brief, p. 290, Van Camp v. Van Camp, 53 Cal. App. 17, 199 Pac. 885 (1921).

285170 Cal. 621, 151 Pac. 12 (1915).

$298 \mathrm{Id}$. at $623,151 \mathrm{Pac}$. at 13. (Emphasis added.)

297 See Barlentine, Corporations $\$ \$ 245-50$ (1946); Latrin, Corporations 467-72 (1959); cf. McLaughrin, Bankruptcy $\S 152$ (1956). See also Mechem, Agency $\S \S 543-51$ (4th ed. 1952).

208 Comnjent, 14 CaLIF. L. Rev. 402, 404 n.17 (1926).

209 Moreover, since the community must bear the loss of any debts contracted by the husband if his business is losing money, see Schuyler v. Broughton, 70 Cal. 282, 11 Pac. 719 (1886), it would appear just that the separate property bear the expense of paying for the services of the husband. See Evans, Prinzary Sources of Acquisition of Community Property, 10 CarTr. L. REv. 271, 282-83 (1922); Coinment, 14 CALIF. L. Rev. 402 (1926).

300 "The usual method of apportionment is to allocate a fair return on the investment to the separate property. ..." Estate of Neilson, 57 Cal.2d 733, 740, 22 Cal. Rptr. 1, 5 (1962). 
a fair return, it would then not matter which interest was subtracted first. It would appear that this is the only way an apportionment can be made under the Pereira approach while adhering to its correct interpretation as stated in Gold. ${ }^{301}$

Any problems remaining after the Neilson decision will exist because two basically conflicting methods of apportionment continue to be used. By setting up Pereira as the usual method, Neilson may have provided the groundwork for resolving this conflict. Nevertheless, the failure to indicate when and if Pereira must yield to $\operatorname{Van} \operatorname{Camp}$ leaves room for the confusion of the past to project itself into the future. If a satisfactory method of apportionment is to be established, it must at least be recognized that past cases have been decided along two separate lines of analysis. A choice can then be made as to which is more suitable, or perhaps a decision can be made to establish another approach not bound up with any of the previous approaches.

\section{IV}

\section{A SUGGESTED SOLUTION}

\section{A. Evidentiary and Procedural Framework}

The problems of apportionment cases may vary with the size and nature of the business, the extent of the spouses' participation, the business climate, and other factors. Since no rigid formula could do justice in every fact situation, a more reasonable approach would seem to consist of a broad framework within which the various facts all may be considered. This franework should determine the issue presented, the party having the burden of proof, and the type of evidence to be considered. ${ }^{302}$

301 See text at note 296 supra.

302 Although the Neilson decision and much of the discussion following hereinafter are written in terms of a husiness belonging to and operated by the husband, it should be clear that the principles discussed are equally applicable to cases involving a separate property business owned and operated by the wife. While there are cases holding that a husband allowing his wife to run her own business makes an implied gift of her earnings by allowing her to control them, Diefendorff v. Hopkins, $95 \mathrm{Cal} .343$, 30 Pac. 549 (1892); Smith v. Smith, $47 \mathrm{Cal}$. App. 650, 191 Pac. 60 (1920), this result probably would not apply after 1951 as the wife now is given the right to control and manage the "community property inoney earned by her," in CAI. Crv. CodE \$171c. Two other situations to be treated similarly to the two already mentioned are where the husband operates the wife's separate business, and where the wife operates the husband's business. In Lewis v. Johns, 24 Cal. 98 (1864), an early case involving a business owned by the wife but run by the husband, the principle was established that a lusband could obtain no interest in the property of the wife by any act of his own. See Lencioni v. Fidelity Trust \& Sav. Bank, 95 Cal. App. 490, 273 Pac. 103 (1928); Gray v. Perlis, 76 Cal. App. 511, 245 Pac. 221 (1926). But see Pacific-Southwest Trust \& Sav. Bank v. Ross, 81 Cal. App. 204, 253 Pac. 351 (1927). This principle was probably founded on the same reasoning that inotivated the court in George v. Ransom. See notes 42 and 44 supra. It would seem clear at present, however, that the earnings attributable to the husband's skill are community property, regardless of whether they are earned by operating his separate property business or that of his wife. But, where it appears that the husband worked in the wife's business without expecting any compensation, it would be proper to hold that the husband had made a gift of his services to the wife. Gray v. Perlis, 76 Cal. App. 511, 245 Pac. 221 (1926). This conclusion is supported by the fact that the husband las control of the commumity assets, CAL. Crv. CoDE $\S \S 172,172 \mathrm{a}$, wlich include the value of his own skill and labor. Under the provisions of CAL. Crv. CoDE $\$ 171 c$, it would seen that the wife similarly could make a gift of her services to her husband's separate business. 
all property obtained during marriage is community property. ${ }^{303}$ This presumption is fundamental to the community property system, and was a part of the system as it existed under early Spanish law. ${ }^{304}$ When applied to apportionment, the presumption should place on the owner of the separate property both the burden of persuasion ${ }^{305}$ and of going forward ${ }^{306}$ to show what portion of the profits are not to be allocated to the community.

The use of the basic presumption in cases involving the classification of profits from a separate property business has been considered previously ${ }^{307}$ But the courts have not followed through with a sound application of the presumption, and often have confused it. ${ }^{308}$ In Estate of Pepper, although the court's analysis began with

303 See note 279 supra.

304 Wilson v. Wilson, 76 Cal. App. $2 d$ 119, 172 P.2d 568 (1946). The presumption is said to be founded upon the likelihood that any property acquired by a spouse during marriage would be community property. 1 DEFuNIAK $\S 60$, at 140. The presumption is also based on the greater precision with which separate property is defined. Horne, Commumity Property-A Functional Approach, 24 So. CaI. L. REv. 42, 52 (1950). See also Evans, The Ownership of Community Properly, 35 Harv. L. REv. 47 (1921). One purpose of the presumption is that it resolves doubts in favor of the community as against questionable claims of separate ownership by third parties and individual spouses. Robbins, Commonity Property Laws 16 (1940); see Clark, Community of Property and the Fammi in New Mexico 20 (1956).

305 Myer v. Kinzer, 12 Cal. 247, 252-54 (1859); Falk v. Falk, 48 Cal. App. 2d 762, 120 P.2d 714 (1941) ; BAIInger § 43; Mechen,, Progress of the Law in Washington Communily Property, 7 Wast. L. Rev. 367, 370 (1933); Pomeroy, Conmunity Property, 4 West Coast Rptr. 357, 358 (1884); Note, 4 Texas L. Rev. 362 (1926); see Fennell v. Drinkhouse, 131 Cal. 447, 63 Pac. 734 (1901); Estate of Boody, 113 Cal. 682, 45 Pac. 858 (1896); Wynn v. Wynn, 170 Cal. App. 2d 484, 338 P.2d 930 (1959); Kenney v. Kenney, 128 Cal. App. 2d 128, 274 P.2d 951 (1954); 1 DEFuntaK $\S 60$, at 140-41. But see Lenninger v. Lenninger, $167 \mathrm{Cal}$. 297, 139 Pac. 679 (1914).

Insofar as the presuniption fixes the burden of persuasion it is more accurately stated as a law determining the character of property than as a rule of evidence. Nilson v. Sarment, 153 Cal. 524, 96 Pac. 315 (1908) ; Jordan v. Fay, 98 Cal. 264, 33 Pac. 95 (1893); McFadden v. Commissioner, 148 F.2d 570 (5th Cir. 1945) ; McKaY, Community Property \& 256 (1st ed. 1910); see Clark, Presumptions in New Mexico Community Property Law: The Califormia Infuence, 25 So. CaI. L. Rev. 149, 163 (1952). See generally 1 deFuniaK $\$ 60$. The basic presumption should be given added force by the California doctrine that presumptions themselves are to be treated as evidence. 1 Jones, Evidence $\$ 117$ (5th ed. 1958); 2 Stanbury, California Trial and Appellate Practice $\$ 1024$ (1958); see Jolly v. Rea, 196 Cal. 547, 238 Pac. 353 (1925) ; cf. Thompson v. Davis, 172 Cal. 491, 157 Pac. 595 (1916). See generally 9 WiGMORE, EVIDENCE § 2490 (3d ed. 1940).

306 See Ganong, Community Property and Presumptions, 28 ORE. L. Rev. 157, 170 (1949). See also Thayer, Evidence at the Common Law 339 (1898); 9 Wigmore, Evidence $\$ 2490$ (3d ed. 1940); Moded Code of Evidence 309-11 (1942). See generally Morgan, Presumptions, 12 Wash. L. Rev. 255, 259-66 (1937).

307 In Lake v. Bender, 18 Nev. 361, 384 (1884), where the entire profit was found to belong to the husband's separate estate, the court stated: "It is conceded that property acquired during coverture presumably belongs to the community. The burden is on the defendant [husband] in this case to overthrow this presumption, by proof sufficiently clear and satisfactory, to convince the court and jury of the correctness of his claim, as in other cases."

308 It has been held that the presumption could be overconie only by "clear and convincing" evidence, Bauer v. Garrett, 79 Cal. 304, 21 Pac. 759 (1889); Thomasset v. Thomasset, 122 Cal. App. 2d 116, 264 P.2d 626 (1953); McBaine, Calmornia Evidence Manual \$ 1294 (2d ed. 1960); Platt, Property Rights of Married Women \$ 14, at 19 (1885), but that "absolute certainty" was not required, Estate of Pepper, 153 Cal. 619, 112 Pac. 62 (1910); Wirz v. Wirz, 96 Cal. App. 2d 171, 214 P.2d 839 (1950). Such language should be taken to mean only that the presumption must be overcome by a preponderance of the evidence. Simonton v. Los Angeles Trust \& Sav. Bank, 205 Cal. 252, 270 Pac. 672 (1928) ; Freese v. Hibernia Sav. \& Loan Soc'y, 139 Cal. 392, 73 Pac. 172 (1903); Wirz v. Wirz, 96 Cal. App. 2d 171, 
the presumption, once the husband traced the property to his separately owned business, the court held that the presumption was rebutted completely. ${ }^{309}$ The soundness of such analysis is questionable. The fact that the husband traces the property to income from his separate investment should not, by itself, overcome the presumption and thereby place the burden of persuasion on the wife who is asserting the property to be separate.

To illustrate a more logical application of the basic presumption, it is useful to view the various steps of proof that are considered in a trial. Initially, the party asserting that the property belongs to the community must establish that the property was acquired after marriage, ${ }^{310}$ since there is no presumption to this effect regarding property held by a married person. ${ }^{311}$ With this much shown, however, the entire value of the property should be presumed to belong to the community. ${ }^{312}$ If it is further established that the property was derived from a separate investment, the property, in the absence of a showing of labor contributions of a spouse, all should be considered separate under the rule of George v. Ransom..$^{313}$ However, if it also is shown that one of the spouses has contributed his efforts to operating the business, the basic presumption should subsist, thereby leaving the burden of persuasion on the party asserting the property to be separate. The use of the presumption in this manner is supported by the community property doctrine relating to commingled funds, ${ }^{314}$ since the property in dispute derives from a commingling of the profits of the separate capital with the value of the community owned

214 P.2d 839 (1950); Estate of Moramarco, 86 Cal. App. 2d 326, 194 P.2d 740 (1948) (degree of proof which produces conviction in an unprejudiced mind); Wilson v. Wilson, $76 \mathrm{Cal}$. App. 2d 119, 172 P.2d 568 (1946) ; cf. Gibson v. Gibson, 126 Cal. App. 2d 534, 272 P.2d 807 (1954). See generally 1 DEFUNIAK $\$ 60$.

309 Estate of Pepper, 158 Cal. 619, 622-23, 112 Pac. 62, 63-64 (1910).

310 In a divorce case the community property becomes an issue if the plaintiff lists in the complaint the property that is contended to belong to the community. 2 WITKIN, CALIForNIA Procedure $\$ 457$ (1954); see 2 Chadbourn, Grossman, \& Van Alstyne, Caltfornia PleadING § 1042 (1961).

311 Fidelity \& Cas. Co. v. Mahoney, 71 Cal. App. 2d 65, 161 P.2d 944 (1945). But cf. Jolly v. Rea, 196 Cal. 547, 555, 238 Pac. 353, 356 (1925), where the court stated that any property existing "at the close of a long marital relation" is presumed to be comnunity property. There were, however, inferences to support a finding that the property was acquired after marriage.

312 See Verrati, Cases and Materials on California Conamunity Property 118-19 (1960); see Austin v. Austin, 190 Cal. App. 2d 45, 11 Cal. Rptr. 593 (1961). See also Kenney v. Kenney, 128 Cal. App.2d 128, 274 P.2d 951 (1954).

31315 Cal. 322 (1860); Verrate, Cases and Materials on California Comarunity Property 118 (1960); see Gudelj v. Gudelj, 41 Cal.2d 202, 210, 259 P.2d 656, 661 (1953). See Estate of Boody, 119 Cal. 402, 51 Pac. 634 (1897), where the court stated that the presumption of community property is rebutted and overcome by proof that the property was acquired by the ordinary use of his separate property.

314 In community property states, a presumption exists that a conmingled fund belongs entirely to the community. 1 DEFUNIAK $\$ 61$. If a portion of the fund can be traced to separate property, it will be characterized as separate property. Belmont v. Belmont, $188 \mathrm{Cal}$. App. 2d 33, 10 Cal. Rptr. 227 (1961); Garten v. Garten, 140 Cal. App. 2d 489, 295 P.2d 23 (1956); Kenney v. Kenney, 128 Cal. App. 2d 128, 274 P.2d 951 (1954); see Wynn v. Wynn, 170 Cal. App. 2d 484, 338 P.2d 930 (1959). But where the fund cannot be traced it is all conclusively presumed to be community property. Falk v. Falk, 48 Cal. App.2d 762, 120 P.2d 714 (1941). This presumption can also only be overcome by a preponderance of the evidence. See Gibson v. Gibson, 126 Cal. App. 2d 534, 272 P.2d 807 (1954). 
Iabor ${ }^{315} \mathrm{Also}$, it has been held that profits from a separately owned business are all community property unless the separate investment was shown to be a factor in producing the income. ${ }^{316}$

Under the foregoing framework the issue is clearly defined to be the determination of the portion of the profits attributable to the separate investment. The burden of persuasion rests on the party asserting some portion to be separate, and failure to carry this burden results in the whole amount being allocated to the community. This approach is not particularly harsh on the spouse owning the separate business, however, since he still is entitled to whatever portion of the profits the evidence supports as being attributable to the separate investment. Moreover, the burden of producing evidence ${ }^{317}$ is placed on the party most able to do $\mathrm{so}^{318}$ since the owner of the business should be in the best position to establish those factors important in evaluating his investınent.

Unlike the Van Camp approach, consideration of the evidence would not be limited to a narrow factual determination. ${ }^{310}$ Various types of evidence could be considered, with each bearing on the issue for whatever weight it might carry. For example, evidence of profits in similar industries could be shown. ${ }^{320}$ Goodwill shown to have been established by the owner of the separate business before inarriage could be considered as a part of the capital investment. ${ }^{321}$ Direct evidence may be introduced regarding the value of the spouse's services to the business, ${ }^{322}$

315 The California Supreme Court considered the profit from a separate property business as a commingled fund before the turn of the century. Estate of Bauer, $79 \mathrm{Cal} .304,21 \mathrm{Pac} .759$ (1889); see Estate of Fellows, 106 Cal. App. 681, 289 Pac. 887 (1930).

316 Austin v. Austin, 190 Cal. App. 2d 45, 11 Cal. Rptr. 593 (1961) ; accord, Estate of Fellows, 106 Cal. App. 681, 289 Pac. 887 (1930); cf. Estate of Gold, 170 Cal. 622, 151 Pac. 12 (1915).

317 See note 306 supra.

318 See Wilson v. Wilson, 76 Cal. App. 2d 119, 172 P.2d 568 (1946); McKaY, Community Property $\$ 210$ (2d ed. 1925); Ganong, Community Property and Presumptions, 28 Ore. L. REV. 157, 167 (1949). This is one of the recognized reasons for the existence of presumptions, Morgan \& Maguire, Cases and Materials on Evidence 88-90 (2d ed. 1942); see McCornick, EVIDENCE $\S 309$, at 643 (1954); cf. Maguire, Evidence of GuItt 100 n.9 (1959); Prosser, Toris $\$ 42$, at 209-10 (2d ed. 1955). See also Ramsdell v. Fuller, 28 Cal. 37 (1865). See generally Morgan, Techniques int the Use of Prestemptions, 24 Iowa L. REv. 413, 416 (1939); Morgan, Presumption, 12 Wase. L. REv. 255, 257-59 (1937); Morgan, Some Observations Concerning Presumptions, 44 Harv. L. REv. 906, 924-31 (1931).

319 See text following note 276 supra.

320 See note 287 supra.

321 Where a spouse has operated his separate busimess prior to marriage, he owns not only the tangible capital assets of the busmess, but also the goodwill or earning potential he has established. But when a man enters marriage and brings with him a certain aunount of previously acquired skill, the monetary returns obtained through the use of this skill belong to the community. In Thomasset v. Thomasset, 122 Cal. App. 2d 116, 264 P.2d 626 (1953), the husband, a lawyer, tried to establish that the earnings from his practice were due in part to the goodwill he had built up during the years prior to marriage. The husband argued for an apportionment of the income, even though he had to work to account for all of it. Apparently, the only evidence introduced by the husband to substantiate his theory consisted of salaries paid to attorneys employed by the county and city. The court ruled such evidence irrelevant, thus leaving nothing of the apportionment theory based on the husband's goodwill investment. It would seem, however, that relevant evidence could have been introduced concerning goodwill by showing, for example, how many of the husband's chents during unarriage were established prior to inarriage. Some reasonable percentage of the fees received from such chients could then be attributed to the goodwill, with this percentage being apportioned to the husband's separate estate.

322 This would be the only type of evidence to be considered under the Van Camp ap. proach. See text following note 276 supra. 
which might include job offers made to the spouse during marriage or salaries earned in employment other than with the separate business. Testimony regarding the salary of other persons in similar job positions, or of the cost to hire another person to run the separate business, could also be considered. ${ }^{323}$ The size and nature of the business may also bear on the value of the spouse's efforts to the business. ${ }^{324}$ Evidence could be shown relating to the general business climate. ${ }^{325}$ Similarly, general rises in land values are relevant where there has been appreciation with little or no improvement to the land in question. ${ }^{326}$

As countering evidence in behalf of the community, it might be shown that the business was not capable of being run successfully without the owner-spouse's efforts. ${ }^{327}$ Also, evidence of the type described above could tend to minimize or eliminate any return on the investment, as for example a showing that the particular industry has not been profitable.

This suggested framework does not differ greatly from the apportionment method established by Neilson. Most significantly, if Pereira is the usual method it still is possible for the holder of the separate investment to gain some portion of the profits without introducing any evidence bearing on the issue of apportionment. He may be entitled to a fair return so long as the property in dispute is traced to the separate investment. ${ }^{328}$ In comparison, under the above analysis an apportionment to the separate property interest would be made only upon evidence supporting a finding that the separate investment was partially responsible for the profits. Without such evidence everything would be community property under the basic presumption. Nevertheless, depending on how the various factors set forth in Neilson are to be used in modifying Pereira ${ }^{329}$ the Neilson approach may closely approximate results under the suggested framework. If such factors are used only to modify the "fair return" under Pereira, rather than switching to a Van Camp inquiry, ${ }^{330}$ the burden in effect is placed on the holder of the separate

323 This might be less rehable evidence because it would estabhish directly only the worth of the person whose salary is shown.

324 For example, while the spouse may have a yearly earning capacity of $\$ 25,000$ in relation to possible employment as a corporate executive, the value of his productive capacity to the separate business is likely to be a lesser figure where such business is a neighborhood grocery store which is not able to fully utilize the spouse's abihty. This raises the issue of whether the community is entitled to the value of the husband's services determined apart from their value to the business in which the husband is working. Since the husband can choose the mode of hiving for the community, CAL. Crv. CODE $\$ 103$, he is able to choose to work in a position where he is less valuable to his employer than in another position, and this should hold true even if he chooses to work in his own separately owned business. This situation should be distinguished from that of a losing business, where the husband may be valuable to the business even though it is not realizing any overall profit. See text following note 330 infra.

325 See Gilmore v. Gilmore, 45 Cal. 2d 142, 287 P.2d 769 (1955).

326 See Mayhood v. La Rosa, 58 A.C. 510, 374 P.2d 805, 24 Cal. Rptr. 837 (1962); Estate of Heltcel, 200 Cal. App. 2d 398, 19 Cal. Rptr. 352 (1962).

327 If, for example, the husband's personal contact with consumers was necessary, this would indicate that the profits were dependent on his efforts. On the other hand, if the husband's duties were primarily ministerial, it would indicate that his duties could have been readily assumed by someone else.

328 This does not mean that the separate investinent always will be entitled to some return under the Pereira rule. In the case of the losing or marginally successful business, an apportionment to the separate estate might not be made if it would be to the detriment of the community. See text following note 292 supra.

329 See text following note 269 supra.

330 See text accompanying note 271 supra. 
investment to show what portion of the profits are attributable to his investment. If Pereira is completely abandoned under Neilson, then the results are likely to differ more drastically from those of the suggested framework, much in the same manner as they would from a strictly Pereira analysis.

\section{B. The Losing Business}

A decrease in the value of a separate property business should be treated in generally the same way as an increase. The first impression in such cases, however, might be that the entire value of an investment that has declined is all separate property. ${ }^{331}$ This notion is perhaps based on the misconception that the Pereira rule always entitles the capital to some rate of return. It has already been shown, however, that Pereira should not require allocation to the capital to the detriment of the community. ${ }^{332}$ The community is entitled to the value of the spouse's efforts, and this is not altered when the service is rendered to a losing cause.

Suppose that $H$ and $W$, after five years of marriage, are obtaining a divorce, and the only property in question is a business that $H$ owned before marriage and continued to operate during the five year period. $W$ has been employed elsewhere, and her earnings have been used for the general expenses of the family. At the time of marriage $H$ 's business was valued at $\$ 125,000$, but at the end of the five years it is worth only $\$ 100,000 . H$ has taken no money out of the business in the five years. During the same period of time other similar businesses of about the same size and character have declined about forty per cent in value, so that a business valued at $\$ 125,000$ five years ago would now be worth $\$ 75,000$. During the marriage $H$ had the opportunity to give up his position with the business and take another job at a salary of $\$ 10,000$ a year. Under these facts, $W$ initially could argue that the business would be worth less than $\$ 100,000$ had it not been for $H$ contributing his efforts, and that the community is therefore entitled to some portion of its value. This contention is supported by the showing of decrease in value of other businesses. Moreover, had $H$ hired someone else in his place, the $\$ 100,000$ would be diminished at least by the salary paid to such other person. ${ }^{383}$

The foregoing might be said to force $H$ to choose between taking another job or having his business lose its separate character. However, while it is true that $H$ has the power to choose the mode of living during marriage, ${ }^{334}$ and to manage the community assets, ${ }^{335}$ his skill is an asset that belongs to the community, ${ }^{336}$ and the community is entitled to whatever value it reaps. ${ }^{337} H$ should not be able to deprive the community of the value of his skill used to keep his separate estate intact any more than he could otherwise improve his separate property with com-

331 Since the impression was that the separate property was entitled to a reasonable interest return even if that consumed all the profits, see text following note 292 supra, where there was no profit at all it would follow from such reasoning that the community likewise gained no interest.

332 See text following note 292 supra.

333 Note, 14 Catrf. L. REv. 402 , 404 n.17 (1926). Estate of Cudworth, 133 Cal. 462, 65 Pac. 1041 (1901) (concurring opinion); see Pomeroy, Husband's Separate Estate, 4 WEST CoAst Rptr. 193, 195 (1884).

334 Cal. Civ. Code \$ 103; see Vosburg v. Vosburg, 136 Cal. 195, 68 Pac. 694 (1902); 1 ARMSTRONg 159.

335 Cal. Civ. Code $\$ \$ 172,172 \mathrm{a}$; see 1 deFundak $\$ 113$, at $322 ; 3$ Vernier, AMerican FanriLy Laws 218-19 (1935).

330 See note 143 supra.

3373 Vernier, American FamiLy Laws 214 (1935). 
munity funds. ${ }^{338}$ Similarly, just as $H$ is not entitled to give away community property without receiving consideration, ${ }^{339}$ he should not be allowed to give his services to the business without having the community receive sone compensation. No matter what apportionment theory is applied it is clear that the community should be entitled to some amount.

A variation of the foregoing hypothetical illustrates a situation wherein the community's interest in a losing business is even more apparent. Suppose that during the first two years of marriage the business grew to a value of $\$ 200,000$, while other similar businesses grew at some rate less than this. If the marriage were to be terminated at this point, the community would clearly have some interest in the successful business, which could be apportioned as suggested above. If, however, the divorce occurs three years later, at a time when $H$ 's business has dropped to a value of $\$ 100,000$, while most other similar businesses have become bankrupt, how is the property to be apportioned? Does the community lose the interest it had in the business because the divorce, or perhaps the death of $H$, occurs at a time when the value of the business has dipped below the value at the time of marriage? It would seem clear that whatever community interest was created while the business was successful should in some manner continue until the time of the dissolution of the marriage. ${ }^{340}$ In deciding what the value of the community interest is, no single factor should be controlling. The cost of hiring someone in $H$ 's place, the amount of job offers to $H$, and the general extent of decline in the industry should all be weighed.

The major change in applying the suggested framework to a losing business would have to be with regard to the initial burden of proof. Inasmuch as the business would not appear initially to be property acquired during marriage, it would not be readily subjected to the basic presumption of community property. Therefore, $W$ would have to bear the burden of showing that $H$ 's services had some value to the business. Once $W$ has carried this burden, $H$ should have to show what part of the business would have remained intact even had he not worked in it. He would clearly be in the best position to produce this type of evidence, and preserving the basic presumption to this extent would not seem unjustified once the wife has connected the husband's efforts to the business.

$W$ could establish the significance of the husband's efforts by showing the much larger decline in other similar businesses. Evidence regarding the type of business, nature of $H$ 's duties, and importance of capital could also be used in this respect.

338 Dunn v. Mullan, 211 Cal. 583, 296 Pac. 604 (1931) ; Provost v. Provost, 102 Cal. App. 775, 283 Pac. 842 (1929). See Comment, 50 CALTE. L. REv. 844 (1962).

339 CAL. Crv. Code $\$ \S 172,172 a$; see Union Mut. Life Ins. Co. v. Broderick, 196 Cal. 497, 238 Pac. 1034 (1925).

340 As to valuation of the community's interest, it would seem too harsh to conclude that the community should not in some way bear part of the decline in the value of the business. If it is found that the commumity interest after the first two years was $\$ 100,000$, there would be nothing left for the separate estate at the end of the five year period if the community is not affected by the decline. Perhaps a better way to express the community's interest in the business would he to determine at the end of each year the proportion of the value of the husband's services in relation to the total value of the business. Such percentage could be established for each year that the husband does not withdraw a salary corresponding to the value of his services, with the community's percentage interest then being traced through the ensuing years in effect as an investment in the separate business. Thus, for example, if after the first two years the commumity has acquired a $50 \%$ interest in the business, the decline during the next three years would be shared half by the commumity. This is without considering any further interest acquired by the community for the value of $H$ 's services during these three years. 
Once $H$ 's connection is shown, it could be presumed that the business would have declined in value at about the same rate as the other businesses, with the burden resting on $H$ to prove that his separate estate is entitled to a greater valuation. He could show this, for example, by evidence of the comparative situation of his business in the industry before marriage. If he had built up goodwill prior to marriage, and his busimess was generally superior in the industry, it could be established that his business would not have dropped in accordance with others. To the extent that $H$ proves his business to have a higher earning power than the general industry, the value of the business would be apportioned as separate property.

\section{CONCLUSION}

The problem of apportioning profits between the community and separate estates could be completely avoided by a constitutional amendment conforming to the original Act of 1850, ${ }^{341}$ thereby overruling George v. Ransom and making the rents and profits of separate property all community property. ${ }^{342}$ However, such reform does not appear forthcoming; therefore, a method for apportionment must be formulated by which the trial courts can proceed rationally to determine the conflicting interests.

It must be realized that the underlying presumption of the community property system is that whatever is earned or acquired by the spouses during marriage belongs to the community. ${ }^{343}$ The introduction of the common law influence in George v. Ransom adnittedly has made a basic change in this system. If, however, this change is to result in situations where long years of inarriage can terminate with no community property having been acquired, ${ }^{344}$ then the purpose of the community system will have been defeated ${ }^{345}$ While it is perhaps easy to understand the deviations from community property law in the early years, the courts in recent times have shown a better understanding of the comnunity property system. Nevertheless, the principles used today in attempting to deal with the complex problem of apportionment are the same ones that developed from the early misunderstanding of the community property system which gave rise to the problem. If a solution is to be found, it must result from a full understanding of the past and a realization that the early cases can no more furnish an answer to the problem than did the George decision in creating it.

While it might be best to depart from existing case law where necessary to design a new approach to apportioninent based on fundamental principles of community property law, such development may not be readily expected. Nevertheless, if the present system is to be retained, it is hoped that rational guidelines will be established to prevent random application of the two arbitrary and divergent approaches to apportionment which still confront us.

Edrein S. Saul*

341 The Act of April 17, I850, Cal. Stats. I850, ch. 103, §9. See also Clark, Nere Mexico Community Property Law; The Senate Interim Contmittee Report, in CharMatz \& DaGoeTt, Comparative Studies in Comanunity Property 81, 96-98 (1955).

342 See text following note 37 supra.

343 See notes 279 and 304 supra.

344 See Estate of Cudworth, 133 Cal. 462, 469, 65 Pac. 1041, 1044 (1901) (concurring opinion).

345 See 1 deFuntak \$ 72; Pomeroy, Husband's Separate Estate, 4 West CoAst Rptr. 193, 195 (1884).

* Member, California Bar; Class of 1962. 